\title{
UM ESTUDO ENTRE RUÍNAS: \\ O PROGRAMA RIO SEM HOMOFOBIA E A POLÍTICA LGBTI FLUMINENSE
}

Luan Carpes Barros Cassal ${ }^{1}$

Resumo: Quem paga o preço com o desmonte do Programa Rio Sem Homofobia (RSH) pelo Governo do Estado do Rio de Janeiro? O que possibilita anunciar uma política como sucedida ou fracassada? Quais as condições necessárias para execução de serviços públicos para a população LGBTI? Tal qual a genealogia trabalhada por Michel Foucault, o presente texto recupera registros relativos a alguns momentos do Programa Rio Sem Homofobia para compreensão de lutas, movimentos e processos históricos em operação. Não se trata de uma busca exaustiva e conclusiva de informações, e nem mesmo uma tentativa de desvelar um passado supostamente verdadeiro e definitivo. Não obstante, acreditamos que este texto pode colaborar para a compreensão do tempo presente e não responder, mas, ao menos, tentar extrair implicações das perguntas formuladas. $\mathrm{O}$ texto está dividido em seis itens, organizado a partir da noção de constelação de Walter Benjamin, a agrupar diferentes ideias por semelhanças provisórias. Primeiro, a apresentação de marcadores metodológicos. Segundo, o funcionamento do RSH na última gestão do Governo do Estado do Rio de Janeiro. Terceiro, a análise de processos relacionados à concepção, inauguração e implementação do Programa. Quarto, a discussão referente a serviços anteriores ao RSH, executados por movimentos sociais, com financiamento público. Quinto, a crítica às narrativas de sucesso, numa tentativa de possibilitar miradas diferentes sobre o presente. Por fim, o apontamento para experiências e responsabilidades que ainda (nos) restam.

Palavras-chave: Rio Sem Homofobia; Genealogia; Movimento LGBTI; Políticas públicas.

1 Graduado e Mestre em Psicologia pela Universidade Federal do Rio de Janeiro (UFRJ). Doutorando em Psicologia na Universidade Federal Fluminense (UFF), em doutoramento-sanduíche pelo Centro de Estudos Sociais da Universidade de Coimbra (Bolsista CAPES). Email: luancassal@gmail.com Vol. 01, N. 04, Out. - Dez., 2018 - www.revistas.unilab.edu.br/index.php/rebeh 


\section{De início ${ }^{2}$}

Quando se leva a sério o momento trágico na visão da história de Benjamin, essa força da ação política inovadora não incita necessariamente o otimismo: ela pode perfeitamente provocar, como demonstra abundantemente a história do século XX, resultados aterrorizantes (LÖWY, 2005, p. 151).

Em outubro de 2017, a cidade de Campina Grande, na Paraíba, sediou o III Seminário Internacional Desfazendo Gênero. O evento reuniu pesquisadoras e pesquisadores, gestoras e gestores, estudantes, militantes, artistas, trabalhadoras e trabalhadores das políticas públicas. Oficinas, simpósios temáticos, apresentações culturais, performances, lançamentos de livros, mesas redondas. Em uma dessas, o Professor Doutor Guilherme Silva de Almeida ${ }^{3}$, da Universidade do Estado do Rio de Janeiro (UERJ), avaliou a situação das políticas públicas de seu estado. Mais especificamente, ele discutiu as implicações de ser um servidor com atraso de salário, enquanto a instituição da qual faz parte interrompeu diversas vezes as atividades, pela impossibilidade de manter-se aberta na falta de serviços e procedimentos básicos. Reconhecendo que não é uma situação isolada, o pesquisador destacou também a situação do Programa Rio Sem Homofobia (RSH), principal política LGBTI ${ }^{4}$ do Estado do Rio de

2 De partida, agradeço as imensas contribuições e debates do grupo de pesquisa que faço parte, coordenado pelo Prof. Dr. Marcelo Santana Ferreira e intitulado "Políticas e Poéticas da Transmissibilidade em Psicologia Social", do Programa de Pós-Graduação em Psicologia da Universidade Federal Fluminense (UFF). Em especial, ressalto a revisão atenta e questionadora do pesquisador Allan Dayvidson de Azevedo Menezes, que foi fundamental para a versão final do artigo.

3 Cf <http://lattes.cnpq.br/2981461762793065>

4 Vale destacar que a nomenclatura "Homofobia" tem seu uso progressivamente reduzido no cotidiano dos movimentos sociais e por vezes nas políticas públicas, pois remete diretamente a pessoas homossexuais e à homossexualidade e, de facto, especialmente a homens gays cisgêneros. Assim, nos últimos anos, diversos grupos, pesquisadoras e pesquisadores e movimentos sociais recomendam o uso de termos específicos (como lesbofobia, transfobia, bifobia, dentre outros) para compreender os processos específicos de produção de violação e violência e, por vezes, o uso de LGBTIfobia (ou variações) como uma expressão que remete ao que há de comum em todos os processos. Entretanto, quando da confecção do Programa Rio Sem Homofobia, essa palavra era frequentemente utilizada pelos movimentos sociais, e se firmou em grande parte da mídia e de diferentes políticas públicas. Dessa forma, Homofobia aparecerá no presente artigo sempre que constar dos nomes oficiais de programas e serviços. Entretanto, isso não significa concordância com sua utilização atualmente para descrição ou explicação dos fenômenos de violência, discriminação e violação em função de identidades, expressões e orientações ligadas à gêneros e sexualidades. Da mesma maneira, a sigla LGBTI a representar Lésbicas, Gays, Bissexuais, Travestis, Transexuais e Intersexuais recebe pertinentes críticas por suas evidentes limitações. Há estratégias de acréscimos de letras que especifiquem identificações e/ou utilização de caracteres que indiquem abertura. A sigla LGBT ainda é de uso comum na designação de políticas públicas, inclusive no título previsto da $4^{\mathrm{a}}$ Conferência Nacional de Políticas Públicas e Direitos Humanos de Lésbicas, Gays, Bissexuais, Travestis e Transexuais - LGBT, prevista para 2019. Entretanto, a principal rede de organizações do país, a Associação Brasileira de Lésbicas, Gays, Bissexuais, Travestis, Transexuais e Intersexos (ABGLT) já ampliou sua nomenclatura. Por isso, escolheu-se, aqui, utilizar a sigla LGBTI para designação de políticas, movimentos sociais e o coletivo de pessoas marcadas como dissidentes por conta de orientações sexuais identidades e/ou expressões de gênero, de forma a aproximar-se da sigla utilizada pela ABGLT. Exceção será feita quando a sigla fizer parte de Vol. 01, N. 04, Out. - Dez., 2018 - www.revistas.unilab.edu.br/index.php/rebeh 
Janeiro (RJ), que passou por diversas suspensões e demissões de profissionais em função de falta de pagamentos e de repasses necessários. O professor questionou como garantir a qualidade e a dignidade mínimas para profissionais, usuárias e usuários das instituições quando em condições tão precárias, em nome de um Estado que se mostra desinteressado e/ou incapaz de cumprir com suas obrigações.

Durante o debate, uma pessoa da plateia tentou responder à pergunta. Apontou que não valeria a pena deixar a população LGBTI desassistida, especialmente com o atual recrudescimento da violência. Os serviços de atendimento especializados seriam de suma importância para muitas pessoas e, por vezes, sua única entrada nas políticas públicas. Seria necessário mantê-los abertos, por mais difícil que isso se mostre, pois, esvaziá-los poderia implicar no seu encerramento.

Grande parte das e dos profissionais da UERJ e do RSH (bem como diversos outros setores do funcionalismo estadual) estavam com três meses de vencimentos atrasados. Parte da equipe vinculada ao Programa (e também da UERJ) identificava-se como LGBTI - seria essa, então, uma situação de violência específica? Quem paga o preço para manter uma política pública em funcionamento quando o Governo do Estado não cumpre com sua responsabilidade básica de remuneração? O que possibilitaria anunciar uma política como sucedida ou fracassada? Por que as políticas para população LGBTI poderiam ser aceitas a qualquer preço, em quaisquer condições? Como nossas vidas foram colocadas numa balança entre quais serão (um pouco mais) protegidas e quais serão (um pouco mais) violadas?

\begin{abstract}
A tradição dos oprimidos nos ensina que o 'estado de exceção' ('Ausnahmezustand') em que vivemos é a regra. Perceberemos, assim, que nossa tarefa é originar um verdadeiro estado de exceção [revolucionário]; e com isso nossa posição ficará melhor na luta contra o fascismo. Este se beneficia da circunstância de que seus adversários o enfrentam em nome do progresso, considerado como uma norma histórica. $\mathrm{O}$ assombro com o fato de que os episódios que vivemos no séculos [sic] XX 'ainda' sejam possíveis, não é um assombro filosófico. Ele não gera nenhum conhecimento, a não ser o conhecimento de que a concepção de história em que se origina é insustentável (BENJAMIN, 2012, p. 245, grifos do autor).
\end{abstract}

algum nome próprio a uma política ou serviço, ou em citações literais que utilizem outras siglas. Desde já, reitera-se que a escolha de palavras e siglas feitas no texto são marcadas, inclusive e não somente, por posições de sujeito e hierarquias de poder de quem escreve, no momento em que escreve (nesse caso, um homem cisgênero, gay, branco, jovem, acadêmico, a viver com poder de compra de classe média em um centro urbano). Isso produz restrições e exclusões que esse texto, apesar das tentativas de reduzi-las, não conseguirá impedir totalmente. Mais ainda, a escrita acadêmica não exclui de responsabilidade autoras e autores e, por isso, estamos passiveis à críticas, reclamações e sugestões de quem vier a ler esta publicação.

Vol. 01, N. 04, Out. - Dez., 2018 - www.revistas.unilab.edu.br/index.php/rebeh 
O Programa Rio Sem Homofobia, apresentado como uma inovadora política para população LGBTI quando de sua inauguração, está em ruínas, nas quais se vive e se trabalha. Mas os restos indicam um campo de batalha ao longo da história. Uma luta cinzenta, repleta de corpos, sangue e papéis.

Delineou-se assim o que se poderia chamar uma genealogia, ou melhor, pesquisas genealógicas múltiplas, ao mesmo tempo redescoberta exata das lutas e memória bruta dos combates. [...] Chamemos provisoriamente genealogia o acoplamento do conhecimento com as memórias locais, que permite a constituição de um saber histórico das lutas e a utilização deste saber nas táticas atuais. [...] Trata-se de ativar saberes locais, descontínuos, desqualificados, não legitimados, contra a instância teórica unitária que pretenderia depurá-los, hierarquizá-los, ordená-los em nome de um conhecimento verdadeiro, em nome dos direitos de uma ciência detida por alguns (FOUCAULT, 1979, p. 171).

Tal qual uma genealogia, o presente texto busca recuperar documentos relativos a alguns momentos do Programa Rio Sem Homofobia para compreensão de lutas, movimentos e processos históricos em operação. Não se trata de uma busca exaustiva e conclusa de informações, e nem mesmo uma tentativa de desvelar um passado supostamente verdadeiro e definitivo. Não obstante, acredita-se que este artigo pode colaborar para a compreensão do tempo presente e não responder, mas, ao menos, tentar extrair implicações da cena ocorrida no Seminário. Os dados encontrados são provenientes de diferentes fontes (documentos legais, textos jornalísticos, pesquisas acadêmicas, entrevistas, narrativas textuais); esses elementos empíricos por vezes dispersos foram organizados em ideias que, como sugestão de Walter Benjamin, podem ser comparadas à relação entre estrelas e constelações.

\begin{abstract}
As ideias relacionam-se com as coisas como as constelações com as estrelas. Isto significa desde logo que elas não são nem os conceitos nem as leis das coisas. Não servem para o conhecimento dos fenômenos, e estes de nenhum modo podem servir de critério para a existência das ideias. [...] As ideias são constelações eternas, e se os elementos se podem conceber como pontos em tais constelações, os fenômenos estão nelas simultaneamente dispersos e salvos. [...] A ideia é definível como a configuração daquele nexo em que o único e extremo se encontra com o que lhe é semelhante. [...] O universal é a ideia. Já o empírico será tanto mais profundamente apreendido quanto mais claramente for visto como algo de extremo. $\mathrm{O}$ conceito procede de algo de extremo (BENJAMIN, 2016, p. 22-23).
\end{abstract}

Foram feitos, portanto, agrupamentos de ideias por semelhanças, mesmo que sejam provisórias pois, tal qual as estrelas, encontram-se em movimento, em diferentes 
níveis, tempos e espaços. Assim, a relação entre os fatos históricos (ou corpos celestes) engendram imagens que fazem pensar o tempo em que vivemos.

O texto está dividido em seis itens, tendo esta introdução estabelecido alguns pontos disparadores e metodológicos. A segunda seção trata do funcionamento do RSH na última gestão do Governo do Estado do Rio de Janeiro. A terceira parte analisa processos relacionados à concepção, inauguração e implementação do Programa. A quarta discute questões referentes a serviços anteriores ao RSH, executados por movimentos sociais, com financiamento do poder público. A quinta seção traz críticas às narrativas de sucesso, numa tentativa de possibilitar miradas diferentes sobre o presente. Por fim, a sexta aponta para experiências e responsabilidades que ainda (nos) restam.

\title{
Da política LGBTI em tempos de "crise"
}

\begin{abstract}
Podemos notar certa continuidade entre o processo percursor de fins da década de 1990 e a história mais recente da 'Política LGBT' no Rio de Janeiro no que diz respeito ao pioneirismo, à inovação, ao investimento na construção de uma imagem pública através de um trabalho orientado junto à mídia. Além disso, era articulada de modo original a ação de pesquisadores, ativistas e executores da política [...]. Tal processo se aprofundaria na primeira década dos anos 2000 $\mathrm{e}$, no momento atual, encontra-se seriamente ameaçado dada a crise econômica e política por que passa o estado do Rio de Janeiro (CARRARA et al, 2017, p. 25 , grifo nosso).
\end{abstract}

Agosto de 2016, abertura dos jogos Olímpicos e Paralímpicos do Rio de Janeiro, no estádio do Maracanã. A presidenta eleita Dilma Rousseff estava afastada do governo por um processo de impeachment (posteriormente consumado) ${ }^{5}$. O então presidente em exercício, Michel Temer, fez uma fala tímida e foi alvo de vaias na abertura; o Governador do Estado, Luiz Fernando Pezão, estava de licença médica ${ }^{6}$, mas compareceu mesmo

5 Cf <https://www12.senado.leg.br/noticias/materias/2016/12/28/impeachment-de-dilma-rousseff-marcaano-de-2016-no-congresso-e-no-brasil>

6 Neste e em outros momentos da gestão, o governador Pezão precisou afastar-se por conta de licenças médicas. Quem assumiu interinamente o governo do Estado foi o vice-governador Francisco Dornelles, do Partido Progressista (PP), político ligado à Ditadura Civil-Militar e, posteriormente, gestões neoliberais do governo federal. Além disso, vale destacar que a chapa de Pezão e Dornelles foi cassada em 2017 por abuso de poder econômico e político na campanha eleitoral, mas a medida não foi executada pois aguarda julgamento de recurso no Tribunal Superior Eleitoral. Por fim, quando da revisão deste artigo para publicação, Pezão encontrava-se preso e Dornelles assumiu o cargo como interino até a posse do próximo governador. Cf <https://g1.globo.com/rio-de-janeiro/noticia/tre-rj-mantem-cassacao-de-pezao-aposrejeitar-embargos-de-declaracao.ghtml> e <https://g1.globo.com/rj/rio-de-janeiro/noticia/2018/11/29/pfesta-nas-ruas-do-rio-para-cumprir-mandados-na-lava-jato.ghtml>

Vol. 01, N. 04, Out. - Dez., 2018 - www.revistas.unilab.edu.br/index.php/rebeh 
assim ao evento ${ }^{7}$. Esse cenário era, literalmente, de calamidade pública ${ }^{8}$. De fato, a chamada crise do Rio de Janeiro é noticiada pelo menos desde 2015, quando o Governo do Estado passou a parcelar e atrasar pagamentos a servidores (terceirizados, contratados e estatutários, nesta ordem) e pensionistas, além de não efetivar repasses para empresas, fundações ou órgãos públicos. Essa situação tornou-se cada vez mais acentuada ao longo dos anos de 2016 e $2017^{9}$ e degradou a prestação de todos os serviços públicos, tanto diretamente prestados pelo Estado como também realizados pelas prefeituras com repasses ou por empresas contratadas por licitação ${ }^{10}$.

A política LGBTI fluminense passou por estados específicos de calamidade. Por um lado, fez parte do panorama geral de redução de gastos e serviços, mas também foi atingida diretamente por um movimento conservador e moralizante levado a cabo pelo Governo. No final de 2015, o governador do RJ realizou uma troca de pastas com objetivo de garantir apoio político e fortalecer bases aliadas ${ }^{11}$; com isso, o deputado (e pastor) Ezequiel Teixeira ${ }^{12}$ assumiu a Secretaria de Estado de Assistência Social e Direitos Humanos (SEASDH) responsável, dentre outros, pelo Programa Rio Sem Homofobia, e imprimiu sua marca na gestão:

[...] os Centros [de Referência] localizados no Rio de Janeiro/Capital, Niterói e Nova Friburgo estiveram fechados entre os meses de janeiro e maio [de 2016] por falta de recursos para a sua manutenção. Isso ocorreu durante a gestão de Ezequiel Teixeira como Secretário de Assistência Social e Direitos Humanos. Enquanto esteve no cargo, o gestor mostrou-se totalmente avesso ao tema, disseminando um discurso que associava a homossexualidade à doença. Além disso, atuou fortemente no sentido de desestruturar o programa Rio Sem

7 Cf <https://www1.folha.uol.com.br/esporte/olimpiada-no-rio/2016/08/1799632-abertura-dos-jogos-nomaracana-tem-vaias-a-temes-e-a-governos.shtml>

8 "Uma série de fatores fez com que o governador em exercício do Rio de Janeiro, Francisco Dornelles, decretasse na sexta-feira passada (17/06), faltando 49 dias para o início dos Jogos Olímpicos, estado de calamidade pública por causa da alta dívida do estado. [...] Os motivos para a falência do Rio de Janeiro não são poucos. Entre eles estão a queda no preço do barril de petróleo e consequentemente na arrecadação de royalties pelo estado, a crise do setor petrolífero brasileiro devido ao escândalo de corrupção da Petrobras, a diminuição na arrecadação de ICMS, também devido à crise econômica, os gastos com a organização dos Jogos Olímpicos e da Copa do Mundo e, ainda, falhas na administração das contas públicas". Cf: $<$ https://www.dw.com/pt-br/como-o-estado-do-rio-de-janeiro-chegou-\%C3\%A0-fal\%C3\%AAncia/a19344065>

9 Cf <https://noticias.uol.com.br/politica/ultimas-noticias/2017/08/14/pezao-atrasa-salarios-de-julho-maspromete-quitar-atrasos-ate-sexta-com-excecao-do-13.htm >

$<$ http://agenciabrasil.ebc.com.br/geral/noticia/2017-12/pezao-pede-desculpas-aos-servidores-e-garantesalarios-regulares-em-2018>

$10 \mathrm{Cf}<\mathrm{https} / / /$ www.cartacapital.com.br/revista/964/crise-no-rio-de-janeiro-uma-tragedia-para-apopulacao>

$11 \mathrm{Cf}<\mathrm{http}$ ///agenciabrasil.ebc.com.br/direitos-humanos/noticia/2015-12/troca-no-comando-de-direitoshumanos-no-rio-provoca-criticas-da>

12 Então filiado ao Partido da Mulher Brasileira (PMB).

Vol. 01, N. 04, Out. - Dez., 2018 -www.revistas.unilab.edu.br/index.php/rebeh 
Homofobia, demitindo 78 funcionários e fechando seus equipamentos de atendimento. Após uma expressiva mobilização do movimento LGBT e da sociedade, em fevereiro, tal secretário foi exonerado e iniciaram as negociações para a definição do novo orçamento para a reestruturação do programa. Em abril, a Assembleia Legislativa do Estado do Rio de Janeiro (Alerj) disponibilizou o recurso e os Centros foram reabertos para o atendimento em maio de 2016 (TEIXEIRA, 2017, p. 16-17).

Durante esse período, o gestor do RSH tentou que o Programa mudasse de Secretaria, mas não teve sucesso ${ }^{13}$. Por sua vez, os movimentos LGBTI do Rio de Janeiro, assim como trabalhadoras e trabalhadores desligados dos serviços, realizaram diversas ações por conta do fechamento dos Centros de Cidadania e interrupção do Disque LGBT; mais ainda, protestos ocorreram por conta das declarações discriminatórias do então Secretário, enquanto outras organizações de direitos humanos posicionaram-se pela impossibilidade ética de Ezequiel Teixeira continuar à frente da pasta (COTTA, 2016). A pressão e as denúncias tiveram efeito para que fosse exonerado do comando da $\mathrm{SEASDH}^{14}$; o Programa foi reativado em seguida, com a contratação de novos profissionais. Mesmo assim, as equipes agora reduzidas seguiram com constantes atrasos de salário. O Secretário seguinte, Paulo Melo ${ }^{15}$, afirmou que o objetivo do seu trabalho na pasta, para os Jogos de 2016, seria prevenir crimes contra os direitos humanos ${ }^{16}$. Aparentemente, não estavam incluídos neste caso os direitos trabalhistas da equipe do RSH.

Após a finalização dos Jogos, já em novembro, o governador publicou o Decreto 45.809/2016 ${ }^{17}$ para modificação do Poder Executivo, com objetivo de reduzir cargos e custos. Com isso, a SEASDH passou a ser subordinada à Secretaria de Estado de Saúde. Essa medida foi revogada em 08 de fevereiro seguinte, com o Decreto 45.908/2017 ${ }^{18}$, que

13 "O coordenador do RSH, Cláudio Nascimento solicitou ao governador Pezão a troca de tutela do programa. Para ele, para que o Rio Sem Homofobia sobrevivesse à crise político-financeira instaurada no segundo semestre de 2015 seria primordial que o programa saísse do organograma da SEASDH e integrasse outra secretaria, como a Casa Civil, por exemplo" (COTTA, 2016, p. 108-109).

$14 \mathrm{Cf}<\mathrm{https}$ ///extra.globo.com/noticias/extra-extra/pezao-exonera-ezequiel-teixeira-pastor-secretario-quediz-acreditar-na-cura-gay-18692236.html>

15 Deputado ao Partido da Mobilização Democrática Brasileira (PMDB), atualmente preso. Cf $<$ https://politica.estadao.com.br/blogs/fausto-macedo/toffoli-mantem-deputado-do-mdb-preso-na-cadeiavelha/>

16 Cf <http://www.rj.gov.br/web/seasdh/exibeconteudo?article-id=2906639>

$17 \mathrm{Cf}<$ http://www.fazenda.rj.gov.br/sefaz/faces/oracle/webcenter/portalapp/pages/navigation-

renderer.jspx?_afrLoop=4683231008370744\&datasource=UCMServer\%23dDocName\%3AWCC319522

\&_adf.ctrl-state=b8ds7093h_36>

$18 \mathrm{Cf}$

<http://www.fazenda.rj.gov.br/sefaz/content/conn/UCMServer/path/Contribution\%20Folders/site_fazenda Vol. 01, N. 04, Out. - Dez., 2018 -www.revistas.unilab.edu.br/index.php/rebeh 
transferiu as atribuições da assistência social à Secretaria de Estado de Ciência, Tecnologia e Inovação. Junto com essa fusão de pastas, o gestor responsável pela política LGBTI foi repentinamente exonerado, sem aviso ou justificativa para além da reorganização das secretarias. A preocupação dos movimentos LGBTI, então, era que esse ato significasse um maior enfraquecimento do $\mathrm{RSH}^{19}$.

A preocupação fez sentido. Em 09 de março, o Secretário anunciou a criação de novas subsecretarias e descentralização dos recursos necessários para retomada dos programas de direitos humanos ${ }^{20}$. No dia seguinte, o Governador criou a Secretaria de Estado de Proteção e Apoio à Mulher e ao Idoso $^{21}$, renomeada em 03 de abril para Secretaria de Estado de Direitos Humanos e Políticas para Mulheres e Idosos $\left(\right.$ SEDHPMI) ${ }^{22}$, que absorveu todos os programas da área. Nesse período de transição, nenhum pagamento foi efetuado aos profissionais dos serviços e, em maio, o atendimento foi suspenso pelo Estado ${ }^{23}$.

Os movimentos LGBTI fluminenses fizeram diversos atos e pressões institucionais; com isso, o Ministério Público Federal de Volta Redonda recomendou a reativação do Programa Rio Sem Homofobia ${ }^{24}$, em uma demonstração da força e importância de organizações do interior do Rio de Janeiro. O Estado reverteu sua decisão e, mesmo de forma precária, os Centros de Cidadania e o Disque LGBT mantiveram seu

/legislacao/tributaria/decretos/2017/DECRETO\%20N.\%C2\%BA\%2045908\%20DE\%2008\%20DE\%20FE VEREIRO\%20DE\%202017.html>

19 “[...] essa exoneração, para a gente, sinaliza, sim, um cenário preocupante, de que há a possibilidade do programa se extinguir dentro do governo do estado". Cf <http://agenciabrasil.ebc.com.br/direitoshumanos/noticia/2017-02/com-exoneracao-de-coordenador-movimento-lgbt-teme-fim-do-rio-sem> $20 \mathrm{Cf}$

<http://www.rj.gov.br/web/guest/exibeconteudo;jsessionid=9ECB0BCC0C5E5E40698FE890CF531386.1 portal2?p_p_id=exibeconteudo_INSTANCE_2wXQ\&p_p_lifecycle $=0 \&$ refererPlid=11702\&_exibeconteu

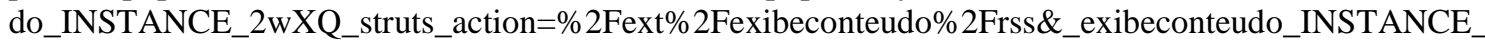
2wXQ_groupId=132962\&_exibeconteudo_INSTANCE_2wXQ_articleId=2759086>

$21 \mathrm{Cf}<\mathrm{http}: / /$ www.silep.planejamento.rj.gov.br/decreto_45_944_-_10032017_-_in.htm>

$22 \mathrm{Cf}$

<http://www.subsecmilitar.rj.gov.br/Legislacao/DECRETO\%20N\%C2\%BA\%2045.972\%20DE\%2003\%2 0DE\%20ABRIL\%20DE\%202017\%20.pdf>

$23 \mathrm{Cf}<\mathrm{https}: / / \mathrm{www}$. revistaforum.com.br/osentendidos/2017/05/10/estado-encerra-atendimento-programario-sem-homofobia-populacao-lgbt/>

$24 \mathrm{Cf}<\mathrm{https} / / / \mathrm{g} 1$.globo.com/rj/sul-do-rio-costa-verde/noticia/mpf-pede-imediata-reativacao-da-estruturado-rio-sem-homofobia.ghtml>

Vol. 01, N. 04, Out. - Dez., 2018 -www.revistas.unilab.edu.br/index.php/rebeh 
funcionamento $^{25}$, com pagamentos irregulares aos profissionais $^{26}$ e redução do funcionamento ${ }^{27}$.

Veja bem, estes serviços públicos continuam a existir pelo esforço de profissionais que sustentam o trabalho sem receber regularmente a remuneração e com risco de demissão a qualquer momento como já ocorreu. E, além disso, também graças ao trabalho incessante dos movimentos LGBTI a manter o funcionamento dos serviços através da luta pública e de mecanismos institucionais. Quando as organizações recusam o encerramento de atividades e trabalhadoras e trabalhadores mantém-se lá mesmo em condições inóspitas, afirmam que a população LGBTI não ficará totalmente desassistida. Dessa maneira, interrogam quem são os elegidos a sofrer os principais efeitos da chamada crise.

\begin{abstract}
A profusão cotidiana de informações - alarmantes para uns, apenas escandalosas para outros - molda nossa apreensão de um mundo globalmente não inteligível. Seu aspecto caótico é a névoa de guerra por trás da qual ele se torna inatacável. É por meio de seu aspecto ingovernável que ele é realmente governável. É aí que está a malícia. Ao adotar a gestão da crise como técnica de governo, o capital não se limitou apenas a substituir o culto do progresso pela chantagem da catástrofe, ele quis reservar para si a inteligência estratégica do presente, a visão de conjunto sobre as operações em curso. E é isso que é importante disputar com ele. Trata-se, em matéria de estratégia, de voltarmos a estar dois passos à frente em relação à governança global. Não há uma 'crise' da qual é preciso sair, há uma guerra que precisamos ganhar (COMITÊ INVISÍVEL, 2016, p. 19, grifo do autor)
\end{abstract}

A narrativa oficial (estatal) de crise não pode ser suficiente. A discussão em um seminário colocava em cena a interrogação sobre quais vidas foram e estão a ser exploradas, sacrificadas, eliminadas, e a quem isso pode atender. Por conta da discriminação e exclusão, a população LGBTI (especificamente, de forma muito mais severa e violenta, as pessoas trans) é fortemente atingida pelo desemprego, subemprego e situações de exploração em ambientes de trabalho precário. Chama atenção que isso se repita na política pública que é executada para garantia de alguns direitos específicos. Imagine qual esta cena: um trabalhador do centro de referência que se identifique como

$25 \mathrm{Cf}<\mathrm{https}$ ///oglobo.globo.com/rio/rio-vive-esvaziamento-de-politicas-dedicadas-populacao-lgbt21349023>

$26 \mathrm{Cf}<$ http://agenciabrasil.ebc.com.br/direitos-humanos/noticia/2017-06/rio-sem-homofobia-buscaparcerias-para-ampliar-centros-de-cidadania>

27 Cf <https://oglobo.globo.com/rio/bairros/niteroi-regiao-registram-um-caso-de-violencia-contra-lgbtspor-dia-21401905>

Vol. 01, N. 04, Out. - Dez., 2018 - www.revistas.unilab.edu.br/index.php/rebeh 
parte da população LGBTI a recorrer ao seu próprio serviço para denunciar a falta de pagamentos.

Manter os serviços abertos significa enfrentar o desmonte do Estado, mas ataca diretamente os direitos de trabalhadoras e trabalhadores. Encerrá-los, por outro lado, implica na desassistência à população LGBTI, especialmente aquela vítima de violências e violações, em um momento geral de restrição do acesso aos serviços públicos. Talvez seja tudo que nos resta. Mas como passamos a disputar as raspas e colocar uns aos outros na linha de frente de violações?

As demissões de técnicos em 2015 e 2016, assim como a ameaça constante de desligamento, é efeito do modo de contratação - precária e temporária - empregada RSH desde sua fundação, uma característica compartilhada por todo o quadro funcional da $\mathrm{SEASDH}^{28}$. O único certame seletivo para estatutários que também poderia atender aos centros de cidadania foi realizado pela SEASDH em 2012, mas foi revogado ${ }^{29}$ pelo então Secretário, Zaqueu da Silva Teixeira ${ }^{30}$. Assim, o risco de encerramento dos contratos, uma condição de possibilidade para aquilo que depois viria a ser identificado como crise, já atravessava os serviços mesmo nos períodos de maior investimento financeiro do Estado $^{31}$. Trata-se de um modo de gestão que coloca serviços e profissionais em risco constante. Hoje, é possível notar ali as condições de possibilidade para o que viria a ser uma crise.

A UERJ, por exemplo, também sofreu severos contenções desde 2015 que levaram a sucessivas interrupções das atividades nos últimos anos - greves docentes e discentes,

28 “[...] em 2012 o órgão não possuía nenhum servidor concursado em seus quadros, compostos majoritariamente por comissionados $(84,7 \%)$, sendo o restante classificado como sem vínculo permanente $(15,3 \%)$. Embora os gestores entrevistados reconheçam que essa é uma fragilidade institucional importante para a condução do SUAS [Sistema Único de Assistência Social], a mudança desse cenário não tem sido prioridade para a gestão estadual" (SENNA, 2016, p.58, grifos nossos).

29 Cf <https://www.cepuerj.uerj.br/App_Upload/S00635-2012.pdf>

30 Deputado estadual, filiado ao Partido Social Democrático (PSD).

31 "De acordo com uma publicação do Programa Rio Sem Homofobia de junho de 2012, até essa data os centros de referência já teriam realizado um total de mais de oito mil atendimentos. Os centros funcionam por projeto, então a cada 12 meses toda a estrutura montada e as ações planejadas correm virtualmente o risco de serem desmanteladas simplesmente por falta de verba ou "vontade política". Para remediar essa situação, o esforço feito é o de comprometer parceiros, envolver outras secretarias e promover muita visibilidade para as ações. Espera-se assim, que a falta de apoio ocasionada por uma eventual troca de gestão que não seja exatamente apoiadora ou comprometida com "a causa", inviabilize a descontinuidade dos serviços, frente ao constrangimento que seria causado entre a população atendida, o movimento social e outros gestores e parceiros envolvidos" (RODRIGUES, 2014, p. 209-210).

Vol. 01, N. 04, Out. - Dez., 2018 - www.revistas.unilab.edu.br/index.php/rebeh 
suspensões e adiamentos de calendário ${ }^{32}$. Estudantes, técnicas e técnicos, professoras e professores, trabalhadoras e trabalhadores terceirizados - todas e todos com bolsas ou salários suspensos, parcelados, atrasados. Ocorreu uma perda substancial do pessoal da comunidade universitária - além das demissões em massa de profissionais terceirizados ${ }^{33}$, houve aumento no índice de evasão de alunas e alunos ${ }^{34}$ e de redução de carga horária e exoneração de servidoras e servidores ${ }^{35}$. Mas também se percebe uma possibilidade de resistir ao projeto de crise e desmonte, ao menos ao corpo decente, através da própria estabilidade do serviço público. Docentes foram pressionados pela falta de pagamentos e condições insustentáveis de trabalho, mas estatutárias e estatutários não puderam (pelo menos, até o momento) ser demitidos à revelia. A Universidade passou por várias interrupções, mas não pode ser encerrada por decisão de um Secretário ${ }^{36}$. A garantia de direitos a trabalhadoras e trabalhadores significa também criar condições para as lutas.

Isso significa que há um risco grande em contar com tempos favoráveis para a execução de políticas públicas, seja no presente ou no futuro. De fato, escolhe-se quais sujeitos podem aguardar, ou receber menos, ou serem levados ao limite. Políticas LGBTI, população LGBTI, mas também trabalhadoras e trabalhadores dos centros de cidadania LGBT - quaisquer encontros com essa pauta são intencionalmente colocados em risco. A existência de uma política pública específica (como o Programa RSH) não é nenhum tipo de garantia para um amanhã, nem da população, e nem da própria política. Entender que o estado de exceção está estabelecido significa reconhecer que as práticas de extermínio continuam a acontecer.

Por outro lado, a presença das ruínas de uma política LGBTI, em constante disputa e ameaça, indica que há uma história que, com imensa luta e interminável esforço, insiste em ser transmitida. Debrucemo-nos, pois, em tais artefatos. O que a história do Programa Rio Sem Homofobia poderia nos contar?

$32 \mathrm{Cf}<\mathrm{https}$ //noticias.r7.com/rio-de-janeiro/apos-greve-e-em-crise-uerj-tem-o-primeiro-dia-de-aula-em2016-29082016> e <https://extra.globo.com/noticias/rio/uerj-suspende-ano-letivo-de-2017-por-tempoindeterminado-devido-crise-21653236.html $>$

$33 \mathrm{Cf}<$ hhttp://g1.globo.com/rio-de-janeiro/noticia/2016/07/rj-pode-ter-que-pagar-r-130-milhoes-porcalote-terceirizados-da-uerj.html $>$

$34 \mathrm{Cf}<\mathrm{http}: / /$ agenciabrasil.ebc.com.br/educacao/noticia/2017-06/crise-dobra-evasao-de-alunos-nauniversidade-do-estado-do-rio-de-janeiro $>$

$35 \mathrm{Cf}<$ https://extra.globo.com/emprego/servidor-publico/docentes-da-uerj-desistem-da-dedicacaoexclusiva-exoneracoes-tem-leve-aumento-21672393.html>

36 Curiosamente, a UERJ hoje faz parte da mesma Secretaria que a pasta de assistência social, com uma imensa discrepância de quadro de servidores estáveis entre as duas.

Vol. 01, N. 04, Out. - Dez., 2018 - www.revistas.unilab.edu.br/index.php/rebeh 


\section{Dos compromissos por um Rio Sem Homofobia}

Algo parecia diferente em 2007 para os movimentos LGBTI do Estado do Rio de Janeiro. Esses grupos já tinham importância e relevância nacional e internacional através de projetos e ações pioneiras na defesa e promoção de direitos humanos, além da denúncia de crimes e violações e, ainda, produzir eventos de visibilidade maciça: as Paradas do Orgulho LGBT. Tamanha força possibilitou a formação de alianças para incidência política em órgãos centrais de governo para indução e promoção de políticas públicas específicas, desenhadas conforme as experiências dos movimentos sociais.

O governador eleito, Sérgio Cabral Filho ${ }^{37}$, do então chamado Partido do Movimento Democrático Brasileiro $-\mathrm{PMDB}^{38}$, já tinha assumido alguns posicionamentos sobre uma das pautas do movimento LGBTI. Quando deputado estadual e presidente da Assembleia Legislativa do Estado do Rio de Janeiro (ALERJ), Sérgio Cabral propôs ${ }^{39}$ o projeto de lei 2.385/2001, que tinha por objetivo garantir aos servidores e às servidoras estaduais direitos previdenciários em caso de "[...] parceria civil do mesmo sexo, [entendida como] as relações permanentes entre pessoas do mesmo sexo, baseadas num compromisso mútuo, laços familiares e amizades duradouras como parte da vida de todo ser humano" ${ }^{40}$. O referido projeto foi aprovado pela Assembleia, mas vetado pelo então governador, Anthony Garotinho ${ }^{41}$, no início de 2002, tendo como justificativa um suposto vício de inconstitucionalidade formal (CARRARA et al, 2017).

Além disso, quando senador, Sérgio Cabral propôs o Projeto de Emenda Constitucional $70 / 2003^{42}$, para “[...] permitir a união estável entre casais homossexuais"43.

37 Atualmente, cumpre pena de prisão em regime fechado. Cf $<$ https://politica.estadao.com.br/blogs/faustomacedo/pena-de-prisao-para-sergio-cabral-chega-a-100-anos/>

38 O partido modificou seu nome para MDB - Movimento Democrático Brasileiro, no final de 2017, num aparente truque eleitoral em que modifica a nomenclatura sem modificar os quadros partidários, o projeto político e os modos de gestão. No presente texto, que trata de eventos anteriores à mudança, será utilizada a sigla PMDB. Cf <hhttps://brasil.elpais.com/brasil/2017/12/19/politica/1513695154_142381.html>

39 Em parceria com o então Deputado Estadual pelo Partido dos Trabalhadores - PT, Carlos Minc. $40 \mathrm{Cf}$

<http://alerjln1.alerj.rj.gov.br/scpro99.nsf/d1b99e6346101855832567040007dd94/ff33df717ac61a6f0325 6a9d006766b8?OpenDocument>

41 À época, filiado ao Partido Democrático Trabalhista - PDT.

42 Cf <https://www25.senado.leg.br/web/atividade/materias/-/materia/61093>

$43 \mathrm{Cf}$

$<$ http://legis.senado.leg.br/diarios/BuscaDiario?tipDiario=1\&datDiario=03/09/2003\&paginaDireta=25788 $>$

Vol. 01, N. 04, Out. - Dez., 2018 - www.revistas.unilab.edu.br/index.php/rebeh 
O projeto tramitou na Comissão de Constituição, Justiça e Cidadania do Senado e, em 2004, a senadora Serys Slhessarenko ${ }^{44}$ e o senador Magno Malta ${ }^{45}$ solicitaram audiência pública para instrução sobre a matéria, o que não ocorreu. Esse projeto foi retirado pelo próprio Cabral em 2006, pouco antes das eleições ${ }^{46}$. De acordo com Cotta (2016), aquela não era uma demanda urgente para os movimentos LGBTI nacionais e por isso, teve uma repercussão limitada; mesmo assim, a militância fluminense cobrou imediatamente um compromisso público do candidato com as pautas específicas ${ }^{47}$. Assim, em seguida ao recuo, Cabral assinou publicamente, e com cobertura da imprensa, a carta-compromisso "Por um Rio Sem Homofobia"48, proposta pelo movimento LGBTI fluminense, com participação do PT.

[...] alguns antecedentes mais imediatos da implantação da Política Rio sem Homofobia remontam a uma carta-compromisso assinada em 10 de outubro de 2006, pelo então candidato ao governo do estado, Sergio Cabral (PMDB). A carta "Compromissos por um Rio Sem Homofobia" consistiu em um documento acordado com lideranças do movimento local e articulado pela deputada federal Cida Diogo (PT) e pelo deputado estadual Carlos Minc (PT), envolvendo 10 "compromissos" em troca de apoio (RODRIGUES, 2014, p. 203).

Após a vitória e a posse, a gestão inicia-se com uma promessa formal de execução de uma política pública específica pelo novo governador, que se colocava favorável a pautas de interesse do movimento LGBTI - ainda que tenha agido conforme as pressões e negociações por apoio político. Sérgio Cabral rapidamente sancionou a Lei 5.034/0749, e, ao mesmo tempo, iniciou a implementação de uma nova política LGBTI.

44 Na época, filiada ao PT.

$45 \mathrm{Na}$ época, filiado ao Partido Liberal - PL.

46 O então senador (e bispo licenciado da Igreja Universal do Reino de Deus) Marcelo Crivella, do Partido Republicano Brasileiro (PRB), afirmou que a retirada ocorreu para que Cabral recebesse seu apoio no segundo turno da eleição ao governo do Estado., versão negada pelo ex-governador. Cf <https://www1.folha.uol.com.br/fsp/brasil/fc0610200609.htm>

47 “A comunidade LGBT reagiu. O movimento a mobilizou e foram realizadas inúmeras manifestações em repúdio à retirada da PEC 70, fragilizando a campanha eleitoral de Cabral. A mídia, mais uma vez, instrumentalizada pelo Movimento LGBT, a partir de um forte trabalho de assessoria de imprensa, que contemplava envio de releases detalhados e folloow up com os principais jornalistas e formadores de opinião, acabou por espetacularizar este processo, conferindo ao debate uma visibilidade que propiciou a emergência das reivindicações LGBT na pauta das discussões prioritárias do segundo turno das eleições de 2006 para governo do RJ" (COTTA, 2016, p. 40-41).

$48 \mathrm{Cf}<$ http://www.abi.org.br/carta-compromisso-por-um-rio-sem-homofobia/>

49 "Em maio de 2007, durante cerimônia realizada no jardim de inverno do Palácio da Guanabara, Sergio Cabral, já governador do estado, sancionou a Lei 5034/07, que nos moldes do projeto anteriormente vetado, prevê a concessão de benefícios para parceiros de mesmo sexo de servidores públicos. Nessa mesma cerimônia, respondendo a um convite de Benedita da Silva, então secretária da SEASDH (Secretaria de Vol. 01, N. 04, Out. - Dez., 2018 - www.revistas.unilab.edu.br/index.php/rebeh 
Entre o início da elaboração do Programa Rio Sem Homofobia (RSH), em 2007, e a implementação do primeiro Centro de Cidadania e do Disque LGBT, em 2010, observamos, no âmbito do poder executivo do estado do Rio de Janeiro, através da Superintendência de Direitos Individuais Coletivos e Difusos (SUPERDIR/SEASDH), um esforço crescente de implantação, expansão e qualificação de ações e serviços voltados para lésbicas, gays, bissexuais, travestis e transexuais. Trata-se da criação de um abrangente e ambicioso dispositivo de proteção contra a discriminação e a violência por preconceito motivado por orientação sexual e identidade de gênero que atua em distintas frentes. De um lado, tal dispositivo tem por função receber variadas denúncias de violações de direitos ou demandas por efetivação de direitos e encaminhá-las a diferentes agências estatais [...]. De outro lado, tem uma ampla função pedagógica ou de promoção de novos valores, lutando, através de campanhas educativas veiculadas na grande mídia ou focalizadas em certas instituições, contra o preconceito que permeia a própria administração pública e a sociedade mais ampla. Finalmente, o dispositivo previsto no Programa Rio Sem Homofobia tem ainda o papel de acompanhar os efeitos de sua própria ação (CARRARA et al, 2017, p. 11-12, grifos do autor).

O RSH configura-se como uma ação direta do poder público a atuar tanto no acolhimento e encaminhamento de situações de violência quanto na promoção de direitos e visibilidade LGBTI. É construída e fiscalizada com participação direta da sociedade civil e, em especial, gerida por um ativista pioneiro do movimento LGBTI, a níveis nacional e internacional, Cláudio Nascimento ${ }^{50}$, à época do Grupo Arco-Íris de Cidadania LGBT. Apresenta-se, assim, uma política inédita e com características específicas e que justificaria a necessidade de práticas inovadoras de gestão.

\begin{abstract}
[Em maio de 2007,] o governador [do Rio de Janeiro, Sérgio Cabral] chamou para conversar com a Benedita [da Silva, então Secretária de Assistência Social e Direitos Humanos], para a gente fazer a sanção da lei e da posse. Nesse momento, eu também negociei algumas coisas na entrada: questão de recurso, de autonomia para nomear a minha equipe e também de ter algum nível de autonomia institucional para determinadas questões, porque, senão... A nossa preocupação era ter uma estrutura muito amarrada, sem condições de dialogar com a sociedade - isso tudo foi acordado e aceito (NASCIMENTO apud CARRARA et al, 2017, p. 218, grifos nossos) ${ }^{51}$.
\end{abstract}

Estado de Assistência Social e Direitos Humanos - RJ), Claudio Nascimento foi empossado como Superintendente de Direitos Individuais, Coletivos e Difusos" (RODRIGUES, 2014, p. 204-205).

$50 \mathrm{Cf}<$ http://claudionascimento.blogspot.com/>

51 Citações literais da fala do então Superintendente Cláudio Nascimento em entrevista realizada pela doutora Sílvia Aguião Rodrigues em outubro de 2011, disponível na íntegra em <http://www.clam.org.br/uploads/arquivo/RetratosDaPoliticaLGBT_RJ_Miolo_170526.pdf>

Vol. 01, N. 04, Out. - Dez., 2018 -www.revistas.unilab.edu.br/index.php/rebeh 
O novo Superintendente conseguiu estabelecer condições para a autonomia pretendida, ao mesmo tempo que possibilitou a participação dos movimentos sociais ${ }^{52}$. Um comitê intersetorial, sob sua coordenação, montou a proposta do Programa Rio Sem Homofobia e organizou a Conferência de Políticas Públicas para população GLBT $^{53}$ do Estado do Rio de Janeiro, precedida por pré-conferências no território fluminense ${ }^{54}$. A conferência contou com grande participação da sociedade civil e foi o espaço deliberativo de aprovação do Programa RSH e do Conselho Estadual dos Direitos da População LGBT $^{55}$ (este, com tarefa de acompanhar e monitorar a política pública), além da promessas de gestores para abertura de diversos serviços para atendimento direto à população LGBTI.

A autonomia na gestão do Programa não significava isolamento. O trabalho do RSH passou a ser assessorado pela UERJ através de um convênio ${ }^{56}$, o que permitiu a contratação de técnicos e estagiários e a realização de pesquisa e extensão universitárias. Assim, o Programa RSH, ao mesmo tempo em que atuava nas políticas públicas intersetoriais, relacionava-se com a produção de conhecimento (na universidade) e com o controle social (do conselho de direitos). Academia, governo e movimentos sociais estavam em tensão, mas em uma produção intensa, que possibilitou uma maior estrutura física e financeira do RSH. Assim, em julho de 2010, o reconhecimento foi materializado em um imenso monumento, com a

52 Vale destacar que a Superdir também foi responsável e produziu ações em outras áreas de direitos humanos, que não serão abordadas no presente texto: "[...] a gente estava priorizando como eixo de atuação a questão LGBT, a intolerância religiosa e a discriminação por estado de saúde - três áreas que a gente abarcou" (NASCIMENTO apud CARRARA et al, 2017, p. 218).

53 A sigla oficial do movimento foi modificada de GLBT para LGBT apenas após a Conferência Nacional de 2008, com objetivo de produzir maior visibilidade para as desigualdades de gênero no movimento. Rodrigues (2014) realizou uma pesquisa etnográfica durante esse período e explica essa mudança em maiores detalhes. Cf <http://www.academia.edu/13157778/Fazerse_no_Estado_uma_etnografia_sobre_o_processo_de_constitui\%C3\%A7\%C3\%A30_dos_LGBT_como_s ujeitos_de_direitos_no_Brasil_contempor\%C3\%A2neo_2014_> $54 \mathrm{Cf}<$ http://g1.globo.com/Noticias/Rio/0,,MUL471156-5606,00-

RIO+PROMOVE+PRIMEIRA+CONFERENCIA+GLBT.html>

55 "Em abril de 2009 foi publicado o decreto que criou o Conselho LGBT do estado do Rio de Janeiro, vinculado a Superintendência de Direitos Individuais, Coletivos e Difusos. De acordo com o decreto, o conselho é composto por 40 integrantes, $40 \%$ do "poder público" e $60 \%$ da "sociedade civil". No poder público estão 12 representantes de secretarias do estado e representantes do Ministério Público Estadual (MPE), da Assembleia Legislativa do Estado do Rio de Janeiro (ALERJ), da Defensoria Pública Geral do Estado do Rio de Janeiro (DPGE) e da Ordem dos Advogados do Brasil (OAB-RJ), um para cada órgão. Configurando um total de 16 integrantes do poder público. As 24 quatro vagas destinadas à "sociedade civill", segundo o decreto ficam distribuídas entre "organizações LGBT" (18 vagas), "organizações de Direitos Humanos" (3 vagas) e "Especialistas e acadêmicos de renomada expertise e trabalho sobre promoção da cidadania LGBT e combate à homofobia" (3 vagas)" (RODRIGUES, 2014, p.208-209).

$56 \mathrm{Cf}<\mathrm{http}: / /$ www.uerj.br/lendo_noticia.php?id=517>

Vol. 01, N. 04, Out. - Dez., $2018 \cdot$ www.revistas.unilab.edu.br/index.php/rebeh 
[...] inauguração de um conjunto de dez serviços a serem oferecidos pela Superintendência de Direitos Individuais, Coletivos e Difusos (SUPERDIR) da Secretaria de Assistência Social e Direitos Humanos (SEASDH) do Estado do Rio de Janeiro. Parte das atividades recebeu o apoio do Governo Federal, através da SEPPIR (Secretaria Especial de Políticas de Promoção da Igualdade Racial) e da SDH (Secretaria de Direitos Humanos). A SUPERDIR funciona no prédio da Central do Brasil, no centro do Rio de Janeiro. O espaço foi cedido no início de 2009 pela Secretaria Estadual de Segurança Pública, que se localiza no mesmo prédio. Todo o amplo espaço, que inclui salas, escritórios e um grande auditório, estava fechado e inutilizado há quase 10 anos e foi totalmente reformado para que pudesse abrigar a estrutura dos serviços. A verba para a reforma, 1,5 milhão de reais, foi liberada pelo governo do estado (RODRIGUES, 2014, p.209).

O prédio da Central do Brasil, entroncamento de diversas modalidades de transporte público, também se torna o cruzamento entre políticas públicas de diferentes níveis e setores ${ }^{57}$, junto com os movimentos sociais (SALLES, 2018). As janelas do sétimo andar exibem uma imensa bandeira do arco-íris, com o telefone de contato do Disque Cidadania LGBT, de funcionamento 24 horas, sete dias por semana ${ }^{58}$. Atendimento contínuo, uma disponibilidade interminável: uma história de progresso.

\begin{abstract}
O primeiro centro de referência foi inaugurado em Nova Friburgo, em agosto de 2010, em seguida foi aberto o Centro da capital, em julho de 2010 [sic], junto com o lançamento do Disque Cidadania LGBT, o seguinte foi inaugurado em Duque de Caxias, em agosto de 2011 e o mais recente foi estabelecido em Niterói, em junho de 2012. E a perspectiva de expansão e abertura de novos centros é sempre destacada. Quanto mais equipamentos instalados, maior é a dimensão da política, não só em sentido estrutural, mas também simbólico (RODRIGUES; 2014, p.211)
\end{abstract}

Com o lema "Um lugar para chamar de seu" (RODRIGUES; 2014, p. 189), os novos Centros de Cidadania LGBT acolhem tanto situações de violência quanto a procura por informações. Para além disso, funcionam como órgãos de referência para encaminhamento e consultoria de questões específicas sobre a população LGBTI. Assim,

57 Outros serviços de direitos humanos também funcionaram no âmbito da Superdir, com sede na Central do Brasil.

58 "O programa RSH disponibiliza um serviço telefônico de atendimento $24 \mathrm{~h}$, ininterrupto e de âmbito estadual, com a finalidade de orientar e acolher LGBT, familiares e amigos em situação de violência e discriminação; além de aconselhar LGBT em situação de crise, que estejam passando por solidão, processo de descoberta, medo, homofobia internalizada, rejeição familiar, entre outros. Também é objetivo do Disque Cidadania LGBT, que atende pelo número 0800 0234567, informar sobre serviços e aç̃̃es voltados para LGBT no Estado (grupos, ONG, serviços públicos, agenda de eventos, locais, etc.) e, dependendo da demanda, encaminhar para a rede de apoio social, prioritariamente para um dos quatro Centros de Referência de Cidadania LGBT" (COTTA, 2016, p. 65).

Vol. 01, N. 04, Out. - Dez., 2018 - www.revistas.unilab.edu.br/index.php/rebeh 
podem absorver tanto as demandas individuais de usuários quanto as necessidades de serviços públicos, privados ou filantrópicos ${ }^{59}$.

\begin{abstract}
Os objetivos definidos para os centros, em termos gerais, reuniam-se em torno de dois pontos: i) oferecer um serviço de "acolhimento" e "encaminhamento" através de "atendimento interdisciplinar (jurídico, social, psicológico)" e ii) funcionar como um centro produtor e irradiador de informações úteis para a mobilização de políticas públicas "de combate a homofobia e promoção da cidadania LGBT". [...] A equipe dos centros de referência é composta por psicólogos, assistentes sociais e advogados, responsáveis pelo atendimento dos "usuários". Completam a equipe os estagiários dessas três áreas disciplinares e o corpo administrativo de funcionários. Além do atendimento direto do público que o procura, a equipe dos centros de referência também se envolve em atividades externas como oficinas, palestras e atividades de formação (RODRIGUES; 2014, p. 217).
\end{abstract}

Estes serviços possibilitaram, ao mesmo tempo, a regionalização do atendimento no Rio de Janeiro, bem como a visibilidade e o reconhecimento oficial, por parte do Estado, da legitimidade das pautas do movimento LGBTI. O Governo do Estado do RJ estava em posição estratégica na garantia de direitos LGBTI, tanto na indução quanto na execução. A implementação do RSH foi apresentada como um enorme sucesso, e apenas o começo. Nesse sentido, a meta era a expansão, dentro dos limites financeiros disponíveis ${ }^{60}$.

\begin{abstract}
A Secretaria [de Assistência Social e Direitos Humanos] tem um orçamento geral, a Superintendência [SUPERDIR] tem uma ação específica para questões de LGBT que, normalmente, é sempre pouco; para nós é pouco, mas em comparação com outros setores, tem bastante porque outros setores não têm nenhum. Em geral, é de R \$ 1,3 milhão, por aí. [...] a gente vai conseguindo o remanejamento de outros recursos para aportar para a superintendência. $\mathrm{O}$ orçamento desse ano [de 2011] chegou a R \$ 3,3 milhões (NASCIMENTO apud CARRARA et al, 2017, p. 224).
\end{abstract}

Os Centros de Cidadania ganharam centralidade na execução do RSH por oferecem atendimento direto à população e contarem com uma equipe especializada para as ações variadas de capacitação, formação, assessoria e elaboração de projetos intersetoriais e políticas públicas, executadas pelo RSH. Portanto, um espaço favorável para circulação e criação de experiências, práticas e alianças. Ao mesmo tempo, também

59 A pesquisa de Salles (2018) apresenta diferentes perspectivas e efeitos dos processos de trabalho dos profissionais do RSH, em especial no encontro entre usuários, centros de cidadania e rede de serviços. 60 O edital de 2013 de processo seletivo para cadastro de reserva de técnicos para o RSH listava pelo menos 10 possíveis municípios para lotação, o que indica o plano de ampliação à época, que não se consolidou. Cf $<$ https://www.pciconcursos.com.br/concurso/programa-rio-sem-homofobia-rj-vagas-ate-2400>.

Vol. 01, N. 04, Out. - Dez., 2018 -www.revistas.unilab.edu.br/index.php/rebeh 
tornou evidentes algumas cisões entre movimentos sociais, especialidades profissionais e produções acadêmicas.

\begin{abstract}
É importante ressaltar que os "técnicos" (psicólogos, assistentes sociais e advogados) só chegaram no início de 2011, quando o Centro da Capital já funcionava com os gerentes e os coordenadores advindos da militância LGBT. A chegada dos "técnicos" trouxe uma questão que atravessaria todos os debates no Programa: a autoridade do "saber científico", vindo da formação acadêmica dos técnicos versus a autoridade do "saber político", construído na militância (LEITE, 2017, p. 244-245).
\end{abstract}

A lógica de autonomia solicitada para a Superdir possibilitou a contratação de quadros do próprio movimento para as funções de coordenação e gestão do RSH e, em seguida, a seleção, via edital, dos técnicos. Ora, o Estado criou serviços especializados, com postos de trabalho para profissões regulamentadas, assessorados por uma universidade pública - de fato, espaços que se diferenciam dos movimentos sociais.

\begin{abstract}
Assim, entre "técnicos" e "políticos" distribuíam-se reclamações. Os investidos do saber "político" diziam que os "técnicos" estariam vivendo pela primeira vez o contato com o cotidiano da população "LGBT" atendida pelos Centros. Essa falta de experiência faria com que não compreendessem muito bem os modos mais apropriados de conduzir o trabalho, pois esse não seria um aprendizado que pode ser garantido na salas das universidade, mas apenas na experiência prática da vida. Enquanto isso, os "técnicos" queixavam-se de não ter a sua competência valorizada e de serem desinvestidos pela coordenação da autonomia necessária para que o seu trabalho fosse conduzido a contento (RODRIGUES, 2014, p. 219).
\end{abstract}

A participação de acadêmicas e acadêmicos nos espaços do poder público de atuação de movimento sociais evidencia as fronteiras estabelecidas entre esses dois campos, e produzem posicionamentos hierárquicos, entre esta militância, que seria a verdadeira, e aquela, que estaria restrita ao espaço seguro das universidades (IRINEU, 2017). Mas uma prática profissional que se pretende apolítica seria, em realidade, um exercício descompromissado com a interrogação da realidade, o enfrentamento das opressões e a possibilidade de transformação social. Afinal, o que se quer com as e os profissionais num serviço?

Talvez a divisão que operava apontasse que algumas pessoas participaram da construção do RSH e dos postos de trabalho que então passam a ocupar (oriundos dos movimentos sociais, tidos como políticos) enquanto outros inscreveram-se em um processo seletivo que tinha requisitos específicos (os ditos técnicos, que necessitavam de

Vol. 01, N. 04, Out. - Dez., 2018 - www.revistas.unilab.edu.br/index.php/rebeh 
formação e registro em conselho profissional). Entradas diferentes, posições de decisão desiguais e, quem sabe, prioridades estratégicas.

\begin{abstract}
Nesse contexto, proliferam lideranças baseadas em centralismo, disputa de poder, autoritarismo e personalismo (quando não, puro estrelismo, de olho na mídia). Em vez da pressão por mobilização comunitária, preferiu-se a estratégia dos lobbies instalados nos corredores do poder central, de modo que poderes locais se prevaleceram de uma somatória de poderes em níveis mais altos, para chegar à proposição de leis e de políticas homossexuais (TREVISAN, 2010, p. $51)$.
\end{abstract}

A entrada das e dos profissionais acontece com um processo seletivo que torna evidente a autonomia da gestão ${ }^{61}$; a formação de uma equipe através de critérios globais de fato não seria possível em um concurso público para estatutários, onde a classificação é impessoal. Além disso, a aposta em uma prática independente e com uma tentativa de diferenciação do que é regularmente reconhecido como poder público também se deu na construção de estratégias de comunicação. Com o objetivo de manter a inovação e aproximar a sociedade das políticas públicas, o RSH apostou na contratação de uma assessoria privada especializada para realização das campanhas publicitárias ${ }^{62}$.

[...] o Rio Sem Homofobia é o único programa de política pública do estado do Rio de Janeiro que [...] tem um site próprio. Isso foi compreendido porque a gente gostaria de uma coisa com uma linguagem mais para a comunidade, que fosse mais gostoso de ler, com imagens etc., porque os sites do governo são todos muito feios, aquelas coisas muito blocadas, foscas, monocromáticas, muito fechados. O governo morre de medo desse negócio de comunicação descentralizada, porque a comunicação de todas as secretarias tem [sic] uma assessoria de comunicação (ascom) única, para todos os órgãos, mas nós, por exemplo, temos a nossa própria ascom (NASCIMENTO apud CARRARA et al, 2017, p. 248)

61 Rodrigues (2014, p. 215, grifos nossos) acompanhou a “[...] formulação do edital e seleção da primeira equipe de profissionais que compôs o CRLGBT, durante os meses de dezembro de 2010 e janeiro de 2011. Ao longo desse processo foi interessante perceber quais eram as características de formação pessoal e profissional consideradas desejáveis para a seleção da equipe de trabalho do serviço. Como, por exemplo, que a equipe fosse diversa em termos de sexo, orientação sexual e cor/raça, inclusive uma tentativa de que na seleção houvesse uma reserva de vagas de trabalho para travestis e transexuais, que se demonstrou juridicamente inviável".

62 "A Comunicação do Programa Rio Sem Homofobia, sem dúvida, é uma área estratégica para o desenvolvimento da política e é coordenada pela Target Assessoria de Comunicação. [...] O trabalho é desenvolvido de forma planejada, a fim de dar visibilidade às ações do RSH, com produção de peças gráficas, releases (textos de divulgação), notas, campanhas educativas e comunicados oficiais da Superintendência de Direitos Individuais Coletivos e Difusos para a imprensa. A empresa já era dona da conta do Grupo Arco-Íris de Cidadania LGBT" (COTTA, 2016, p. 73).

Vol. 01, N. 04, Out. - Dez., 2018 - www.revistas.unilab.edu.br/index.php/rebeh 
Essa estratégia teve um grande impacto, com aumento do número de atendimentos nos serviços durante a divulgação das campanhas especializadas. De fato, um merecido retorno para uma aposta alta e estratégica. "Não só pelo fato de ter custado cerca de sete milhões de reais, investimento robusto para uma publicidade cuja intenção maior era a sensibilização, mas também pelo grau de envolvimento dos atores governamentais e também pela quebra de certos protocolos" (COTTA; 2016, p.75, grifos nossos). Mais ainda, a campanha publicitária divulgava em larga escala a posição do Governo do Estado de defesa dos direitos da população LGBTI. Havia uma importância na escala e no pioneirismo.

\begin{abstract}
A campanha foi alardeada como sendo a primeira do tipo na América Latina, mais uma vez investindo na imagem de "vanguarda". Orçada em 4 milhões de reais, as peças publicitárias contavam com cartazes, inserções em rádio, TV e mídia impressa e materiais promocionais como bolsas, bonés, camisetas, chinelos, cadernos e barracas de praia. [...] Não basta fazer a política bem feita, é preciso fazer e investir para que a política apareça bem feita. Esse tipo de orientação diz algo sobre as formas através das quais o Estado representa a si mesmo. $\mathrm{O}$ espetáculo e a cerimônia da afirmação política, rituais encenados como parte da tecnologia de administração do poder, produzem um modelo exemplar, que pode ser tomado em dois sentidos. Como a representação de um modelo irrepreensível e como mais um exemplar da simulação de um Estado idealizado. (RODRIGUES, 2014, p. 190-191, grifo nosso).
\end{abstract}

A visibilidade da comunicação esteve articulada com a ideia de pioneirismo e inovação. Ser a primeira campanha, o primeiro centro, a primeira política, etc. ${ }^{63}$ Não à toa, cada evento, como a posse do Superintendente, as Conferências, a inauguração da sede do RSH ou o lançamento da campanha milionária, era montado como grande espetáculo, com presença da mídia, de celebridades e autoridades políticas. Cria-se um padrão de evento do RSH.

Solenidades ou lançamentos como os descritos acima não são simples
lançamentos, mas atos públicos que envolvem a montagem de uma cena
reunindo elementos específicos a serem utilizados na produção de uma
determinada imagem para a política. E essa parece ser uma especialidade da
maneira como a "política LGBT" vem sendo constituída no Rio de Janeiro, em

63 “A veiculação e propagação midiática de ocasiões como essa vão se escrevendo na história do estado do Rio de Janeiro e, principalmente, na efetiva entrada dos LGBT nas pautas governamentais. A visibilidade aqui é instrumentalizada pelo Movimento LGBT, a fim de gerar um compromisso público por parte do Governo do RJ com este segmento populacional. É como se a gestão fosse se comprometendo, evento a evento noticiado, com as demandas dos LGBT. Tal emergência e notoriedade vão capilarizando e mobilizando pequenas e grandes instâncias políticas, abrindo brechas em áreas mais conservadoras, onde o trabalho de sensibilização das questões LGBT deve ser feito antes da implementação da política pelos seus executores e multiplicadores". (COTTA, 2016, p.48).

Vol. 01, N. 04, Out. - Dez., 2018 -www.revistas.unilab.edu.br/index.php/rebeh 
que determinados tipos de evento costumam seguir um mesmo script. Quase sempre Jane Di Castro é chamada para interpretar o hino nacional e outras canções. Nenhuma mesa de abertura se faz sem "autoridades". Todos os eventos são produzidos como "marcos".

A presença das "autoridades" é tida como importante por agregar legitimidade: se o próprio governador está presente, isso garante que a política seja compreendida como um compromisso do estado. [...]A retórica que exalta o "pioneirismo" e a "vanguarda" reveste a imagem construída para essa política e é utilizada para falar de todo tipo de "primeira vez". (RODRIGUES, 2014, p.190-191, grifos nossos).

O RSH conseguiu realizar diversas ações, mobilizar imensos recursos financeiros para suas ações, com gigantesca visibilidade, em um momento favorável da política pública, quando não se anunciava crise financeira. O Governador Sérgio Cabral e o ViceGovernador repetiram sucessivas vezes o seu compromisso com a política LGBTI - o que não impediu seu desmonte posterior, em que a gestão do PMDB fez cada vez mais com que a política pública não fosse um lugar para chamar de "nosso". A aposta em autonomia teve como consequência a provisoriedade das ações - profissionais, serviços e campanhas ficaram submetidas a grandes gastos públicos, cada vez maiores com os planos de expansão. Quando o Estado decide reduzir tudo quanto possível, Os resultados extremamente favoráveis do RSH não foram o suficiente para mantê-lo em pleno funcionamento. Talvez o compromisso de governo seja menos por um Rio Sem Homofobia e mais pela conjugação de forças adversárias em uma temporária coalizão.

Mais ainda, essas práticas chamadas de autonomia, com o passar dos anos, tiveram um alto custo tanto para a manutenção do Programa quanto para os corpos de técnicas e técnicos, gestoras e gestores, a serem desligadas e desligados ou a trabalharem sem salários. E talvez isso indique que a política que se imagina dissociada da técnica tenha reduzida sua possibilidade de analisar a produção de fragilidades e riscos nos processos de trabalho e gestão.

\section{Dos mortos no caminho}

Apesar do orçamento que, para a Superdir, era pouco, o Programa Rio Sem Homofobia diferenciava-se de iniciativas públicas anteriores, tanto no que diz respeito à verba quanto as condições de institucionalidade. Dois grupos de iniciativas merecem destaque neste texto, pois ofereceram tipos de serviços que depois foram recuperados pelo Programa RSH.

Vol. 01, N. 04, Out. - Dez., 2018 - www.revistas.unilab.edu.br/index.php/rebeh 
O modelo de centros de referência foi utilizado pelo Governo Federal, através da Secretaria Especial de Direitos Humanos da Presidência da República, que lançou editais de financiamento para 'Centros de Referência de Enfrentamento à Homofobia' $\mathrm{CREHs}^{64}$. No Estado do Rio de Janeiro, este financiamento contemplou ações ${ }^{65}$ em Nova Friburgo (através da Prefeitura Municipal) ${ }^{66}$ e Duque de Caxias (através da Organização de Direitos Humanos Projeto Legal ${ }^{67}$. Os serviços ofereceram atendimento multidisciplinar às situações de violência, concomitantemente com estratégias de prevenção de violações e promoções de direitos (GARCIA, 2011). O funcionamento através de editais possibilitava a realização de ações, mas com prazos de duração, o que ameaçava a continuidade do trabalho ${ }^{68}$. Esses municípios foram posteriormente atendidos pelos Centros de Cidadania do RSH o que, por um lado, permitiu absorver as demandas de atendimento já existentes e, por outro, possibilitou aproveitar parte das estruturas e parcerias já estabelecidas nesses territórios.

Além disso, o Governo do Estado do Rio de Janeiro apoiou o funcionamento do serviço de Disque Defesa Homossexual - DDH, posteriormente denominado Centro de Referência contra a Violência e a Discriminação ao Homossexual do Rio de Janeiro CERCONVIDH, entre 1999 e 2007.

É no panorama do final dos anos 90, já no contexto de multiplicação de ONGs
e redes, na presença das paradas do orgulho, da internet e de um mercado que
crescia, que acontece a primeira experiência de política pública na esfera da
segurança, o Disque Defesa Homossexual (DDH). Criado em 1999, na
[Subsecretaria de Pesquisa e Cidadania da] Secretaria de Segurança do Rio de

64 "A partir das propostas do BSH [Programa Brasil Sem Homofobia], em 2005, foram implantados 15 Centros de Referência em Direitos Humanos e Cidadania Homossexual (CRDHCH) e, no ano seguinte, outros 30, em todas as capitais estaduais e em algumas das principais cidades do país, com o objetivo de prestar assistência jurídica, psicológica e social à população LGBT. Por outro lado, ainda em 2006, a SDH estendeu o projeto dos CRDHCH para as universidades, a fim de investir, com recursos de capital, na implementação de Núcleos de Referência em Direitos Humanos e Cidadania Homossexual (NRDHCH), em oito instituições públicas de ensino superior. Há, todavia, expressivo ceticismo no que diz respeito à efetividade dessas ações" (MELLO; AVELAR; MAROJA, 2012, p.297)

$65 \mathrm{Cf}$

<https://contas.tcu.gov.br/etcu/ObterDocumentoSisdoc?seAbrirDocNoBrowser=true\&codArqCatalogado= 6279352>

$66 \mathrm{Cf}<\mathrm{https} / / /$ avozdaserra.com.br/noticias/centros-de-cidadania-lgbt-do-estado-retomam-atendimento> 67 Garcia (2011) descreve o funcionamento deste centro de referência em sua pesquisa cartográfica. 68 "Em novembro de 2008, foi realizado, em Brasília, o III Seminário de Capacitação dos Centros de Referência em Direitos Humanos de Prevenção e Combate à Homofobia e dos Núcleos de Pesquisa e Promoção da Cidadania LGBT, organizado pela SDH. Em meio a uma tentativa de avaliação dos trabalhos desenvolvidos nos centros e núcleos, a tônica dos discursos de representantes dos diversos estados foi a descontinuidade dos trabalhos, tendo em vista a escassez de recursos e a dificuldade de sustentabilidadedos projetos, sem o apoio financeiro da SDH ou dos governos estaduais e municipais" (MELLO; AVELAR; LAROJA, 2012, p. 297).

Vol. 01, N. 04, Out. - Dez., 2018 - www.revistas.unilab.edu.br/index.php/rebeh 
Janeiro, o DDH foi pensado como um programa de defesa (e não apenas de denúncia). O projeto configurou uma experiência de estabelecimento de parcerias diretas entre polícia e grupos de ativistas, no sentido de fazer agir com rapidez tanto dispositivos de prevenção de crimes (acionando a força policial em locais e situações de incidência de violência), como de atendimento às vítimas dos crimes já ocorridos (mobilizando a polícia para investigar agressores e golpistas e articulando redes de apoio psicológico e jurídico por parte das ONGs). (RAMOS; CARRARA, 2006, p.192, grifos nossos).

O DDH, ao tornar-se ponto de convergência de denúncias e informações, produz dados privilegiados sobre violências e violações, inclusive aquelas que não ganham maior visibilidade. Isso possibilitou uso e reivindicação mais qualificada pelos movimentos sociais. Entretanto, enquanto o RSH contava com técnicas e técnicos de profissões especializadas, o DDH precisava acionar as redes, governamentais ou não, para garantir atendimentos. Para além disso, deveria ser um de diversos centros especializados em questões de violência, como parte de uma proposta de modificação da política de segurança pública fluminense (CARRARA et al, 2017).

A experiência foi desenvolvida no contexto de um conjunto de programas na área de segurança pública que preconizava a democratização e modernização do aparelho policial, prevendo intensa participação de organizações da sociedade civil. [...] Os acontecimentos deflagradores das demandas do movimento homossexual à secretaria de Segurança, que posteriormente motivaram a idealização do DDH, foram sucessivas agressões sofridas por jovens gays numa área de bares e boates GLS em Botafogo, bairro da Zona Sul do Rio de Janeiro, e o despreparo da polícia para atender a essas ocorrências. (RAMOS; CARRARA, 2006, p.192-193).

Como destacam Carrara et al (2017), a experiência do DDH tem relação com a forma de constituição do RSH; além disso, o modo como o serviço foi montado à época diz respeito diretamente à conjunção de forças, movimentos sociais e experiências que havia.

Foram três as iniciativas de organizações não governamentais que desembocaram no Disque Defesa Homossexual (DDH). O "DisqueViolência/Disque Aids", iniciativa do Grupo Atobá, as denúncias de assassinatos realizadas através dos levantamento do Grupo Gay da Bahia (GGB) e da exposição crescente dos casos na mídia e as "campanhas de conscientização, como o alerta sobre o 'boa-noite cinderela', do Grupo ArcoÍris, realizado em 1997". [...] Ainda foi fundamental para que o projeto tomasse forma, a articulação com a ALERJ, através do mandato do deputado Carlos Minc e a parceria com pesquisadores do Instituto de Estudos da Religião (ISER), do Centro Estudos de Segurança e Cidadania da Universidade Candido Mendes (CESeC/UCAM) e do Instituto de Medicina Social (IMS/UERJ).

Vol. 01, N. 04, Out. - Dez., 2018 -www.revistas.unilab.edu.br/index.php/rebeh 
A Secretaria de segurança cedeu o espaço físico, a linha telefônica e o salário de poucos funcionários alocados na Subsecretaria e do gerente do DDH, mas o cotidiano do atendimento ficava a cargo de voluntários recrutados através dos grupos de militância e da colaboração dos parceiros envolvidos no projeto. (RODRIGUES, 2014, p.194)

A montagem deste serviço ocorreu como parte de uma nova política de segurança pública implementada em 1999, pelo então governador Anthony Garotinho no início de sua gestão ${ }^{69}$. O DDH funcionava com recursos do Estado, mas a execução do trabalho ficava por conta dos movimentos sociais. Isso colocava uma dependência da disponibilidade de voluntariado para manutenção do serviço; por outro lado, permitiu que organizações LGBTI realizassem a gestão direta das atividades, compartilhada através de fóruns deliberativos do movimento.

\begin{abstract}
Mas não era uma coisa que estava correta, que estava estruturada para ter um grupo de profissionais naquela equipe atendendo. E como também não era reconhecido dentro da estrutura, então, você não tinha como mandar um ofício para outro órgão cobrando uma determinada questão, porque era visto como um serviço da sociedade civil, apoiado pelo governo, mas não necessariamente tinha a obrigação de setores do poder público darem resposta para aquilo, principalmente setores de segurança, que eram, e ainda são, os mais resistentes a este tipo de questão. Então, nós aprendemos, por exemplo, que era preciso estar dentro da agenda pública, era preciso ser algo assumido pelo governo do estado, algo que estivesse dentro da agenda da secretaria, algo que tivesse a presença de diversos órgãos (NASCIMENTO apud CARRARA et al, 2017, p. 232).
\end{abstract}

Em 2000, o subsecretário e idealizador da política de segurança, Luiz Eduardo Soares, foi exonerado do cargo. Isso colocou o DDH-CERCONVIDH em uma posição de instabilidade. Os pagamentos de ajuda de custo aos voluntários, assim como a garantia dos insumos necessários, eram irregulares e o serviço era modificado conforme as mudanças na gestão ${ }^{70}$. Em 2003, o atendente Ubiratan Ferreira da Silva sofreu uma agressão física de uma oficial da Polícia Militar, enquanto ele trabalhava no setor reservado para o DDH; por conta desta situação, o serviço foi deslocado de prédio e de

69 "A política de segurança, juntamente com outros programas do governo, como os Restaurantes Populares, que ofereciam refeições a baixo custo, e a construção do Piscinão de Ramos, funcionava como espécie de vitrine de grande apelo popular e catalisava a atenção midiática para as iniciativas da nova gestão do estado" (CARRARA et al, 2017, p.19).

70 "Com a troca da gestão, os laços e as alianças que contribuíam para o andamento do projeto foram perdidos e o processo de estruturação da política, interrompido. Como não existia nenhum estatuto formal estabelecendo o serviço, seu funcionamento ficava vulnerável às vontades da administração responsável Porém, mesmo sem grande apoio e eficácia, o DDH permaneceu atuante ao longo da primeira década dos anos 2000, tendo tido suas instalações transferidas para a Secretaria de Estado de Justiça e Direitos do Cidadão" (CARRARA et al, 2017, p. 22).

Vol. 01, N. 04, Out. - Dez., 2018 -www.revistas.unilab.edu.br/index.php/rebeh 
Secretaria. Violência contra um atendente ou contra o serviço? De fato, que tipo de estrutura é essa?

\begin{abstract}
E aí o único erro, não o único erro, não posso dizer erro, porque é o conhecimento acumulado. Uma das fragilidades naquele momento é que não havíamos conseguido ainda um acúmulo de forças para que a política que se iniciava tivesse uma consistência maior do ponto de vista de sua estruturação. No sentido de ter uma equipe técnica estruturada para a ação, de estar dentro da estrutura da secretaria, de não ser algo conduzido pelo movimento, que foi o que aconteceu. [...] Nós tínhamos uma crítica muito forte, havia uma reflexão muito grande de que a gente estava enxugando gelo, tentando fazer uma coisa que não conseguia ter resposta [...] (NASCIMENTO apud CARRARA et al, 2017, p. 232).
\end{abstract}

Com a mudança, o serviço passou a funcionar no edifício da Central do Brasil, onde atualmente é a sede do RSH. Ficava, entretanto, no terceiro andar, com uma divisória de sala, um telefone, duas cadeiras e um atendente por vez. A fragilidade de estruturação não possibilitou a realização de processos seletivos e campanhas publicitárias. A sistematização de dados de atendimento, um dos pontos mais originais e divulgados do DDH, ficou descontinuada até ser suspensa ${ }^{71}$. Talvez a falta de visibilidade tenha contribuído para as condições de seu posterior encerramento.

Uma chacina na Baixada Fluminense resultou na morte de 30 pessoas em 2005. O CERCONVIDH atuou diretamente no caso, garantindo os procedimentos que restavam aos familiares das vidas eliminadas - cadastro e encaminhamento dos parentes, acompanhamento da denúncia, realização do enterro das travestis mortas no episódio, identificação de algumas das vítimas (GAIO et al, 2006).

O ativista Cláudio Alves dos Santos, morador da região atingida, participava diretamente desta ação. Foi sequestrado, torturado e morto ${ }^{72}$. Violência contra um ativista ou contra o serviço: pode-se diferenciar? O coordenador do serviço também sofreu ameaças de morte. Alguns dos então poucos colaboradores do DDH ficaram com medo

71 “A experiência do DDH disparou a implementação de outras iniciativas semelhantes na época, em Belo Horizonte, Brasília e Goiânia. O centro de referência e o DDH continuaram a funcionar de forma bastante enfraquecida até 2006, durante esse período houve algumas tentativas de reestruturação, mas a sistematização dos dados foi descontinuada". (RODRIGUES, 2014, p.200).

72 "Cláudio Alves dos Santos, ativista em defesa dos direitos dos homossexuais, foi cruelmente torturado e assassinado, em Nova Iguaçu, Rio de Janeiro. O Centro de Referência contra a Violência e Discriminação ao Homossexual (CERCONVIDH), no qual Cláudio atuava, recebe constantes ameaças por sua atuação na defesa dos direitos de homossexuais, lésbicas, travestis, transexuais e transgêneros. Cláudio Alves dos Santos, ativista em defesa dos direitos dos homossexuais no Rio de Janeiro, desapareceu no dia 17 de outubro de 2005. Três dias depois de seu desaparecimento, foi encontrado morto com sinais de tortura e espancamento, com os olhos vazados e ferimentos causados por arma de fogo" (GAIO et al, 2006, p.63).

Vol. 01, N. 04, Out. - Dez., 2018 - www.revistas.unilab.edu.br/index.php/rebeh 
de continuar as atividades, tendo em vista o descaso do poder público na garantia da sua segurança:

\begin{abstract}
Com o recente assassinato de Cláudio, alguns membros do Disque Defesa Homossexual estão deixando o trabalho, pois estão com medo e são pressionados por suas famílias que temem por suas vidas. As organizações de direitos humanos que atuam na área dos direitos dos gays, lésbicas, bissexuais e transexuais em todo o país têm se manifestado por diversos meios com grande preocupação pelo número crescente de lideranças ameaçadas e assassinadas. (GAIO et al, 2006, p. 64-65).
\end{abstract}

Qual o preço para a manutenção de um serviço? O DDH deveria ser mantido a todo custo? O encerramento do CERCONVIDH diz não apenas da falta de apoio direto do governo ao serviço, mas da omissão do Estado na investigação de crimes bárbaros de violência, e da expectativa que continuassem a acontecer - e, de fato, continuam.

Com quantas vidas se faz uma política pública? Quem matou Cláudio Alves dos Santos?

\title{
Do progresso fracassado
}

\begin{abstract}
A atitude de [Walter] Benjamin consiste exatamente em inverter essa visão da história, desmistificando o progresso e fixando um olhar marcado por uma dor profunda e inconsolável - mas também por uma profunda revolta moral - nas ruínas que ele produz (LÖWY, 2005, p. 92).
\end{abstract}

Sérgio Cabral foi reeleito governador com ampla maioria de votos no primeiro turno das eleições $2010^{73}$. A materialização dos compromissos assinados na campanha anterior com a efetivação do Programa RSH, de ações em diversas frentes estratégicas, foi razão para o apoio de diversos movimentos sociais, dentre os quais parte das organizações LGBTI fluminenses

Uma outra coisa que eu acho que não se pode descartar dessa relação é a
presença da militância de direitos humanos de esquerda nesse processo de
relacionamento com a política pública e com o governo atual que se constituiu
[do PMDB]. É também uma nova aliança, uma aliança mais progressista, que
teve a presença de partidos mais progressistas, como o PT, o PSB [Partido
Socialista Brasileiro]. É importante dizer isso, porque é a característica de um
governador [Sérgio Cabral], vamos dizer, antenado com esse debate há muitos
anos, então, tudo também confluiu para uma atmosfera mais favorável. Muita
gente que estava fora entrou no governo - e não só do movimento LGBT, mas
de vários outros movimentos. Confluiu um pouco desse lugar da agenda de

73 Cf <http://g1.globo.com/especiais/eleicoes-2010/noticia/2010/10/sergio-cabral-e-reeleito-governadordo-rio-de-janeiro.html $>$

Vol. 01, N. 04, Out. - Dez., 2018 - www.revistas.unilab.edu.br/index.php/rebeh 
direitos humanos, tanto é que aqui estão começando a discutir a questão da polícia cidadã [as Unidades de Polícia Pacificadoras - UPPs], claro que tem muita crítica até hoje e ainda há muita coisa que precisa avançar, mas já se acumulou muitas coisas nessas últimas gestões, não é? (NASCIMENTO, apud CARRARA et al, 2017, p. 244-245).

Em 2011, durante o segundo mandato e a ampliação do RSH, a Arguição de Descumprimento de Preceito Fundamental proposta pelo governador Sérgio Cabral, foi julgada pelo Supremo Tribunal Federal em 2011, em conjunto com a Ação Direta de Inconstitucionalidade 4277, e garantiu a equiparação das relações entre parceiros do mesmo gênero com as uniões estáveis de casais heterossexuais ${ }^{74}$. A aliança com ares progressistas indicaria o trabalho pela garantia dos direitos humanos.

Sérgio Cabral renunciou ao cargo em 03 de abril de 2014 e era cotado como candidato ao Senado Federal ${ }^{75}$, enquanto o vice-governador Luiz Fernando Pezão foi escolhido para pleitear a sucessão do governo. Entretanto, uma série de denúncias de corrupção e de uso indevido da máquina pública, além de um desgaste de sua imagem com a violenta repressão policial contra as manifestações populares de 2013 e 2014 contribuíram para sua desistência da candidatura ${ }^{76}$. O PT, aliado do governo Cabral, que ocupou a chefia da SEASDH durante grande parte da implementação e execução do RSH, rompeu com o governo do PMDB no início de 2014 para apresentar candidatura própria ao governo do Estado. A separação trazia também tensões a nível federal, com parte do PMDB a apoiar a candidatura do Partido da Social Democracia Brasileira (PSDB) à presidência da república, apesar de formalmente ocupar a vice-presidência na chapa do $\mathrm{PT}^{77}$. A aparente coalizão progressista estava em frangalhos. A divisão de partidos na disputa e a renúncia do governador não impediram nem modificaram, naquele momento, o funcionamento e a gestão do RSH.

Parte do movimento LGBTI fluminense apoiou Pezão em sua candidatura ao Governo do Estado. De fato, seu plano de governo assumia publicamente o compromisso com a manutenção do $\mathrm{RSH}^{78}$. A disputa do segundo turno aconteceu entre o candidato do

$74 \mathrm{Cf}<$ http://www.stf.jus.br/portal/cms/verNoticiaDetalhe.asp?idConteudo=178931>

$75 \mathrm{Cf}<\mathrm{http}: / / \mathrm{g} 1$.globo.com/rio-de-janeiro/noticia/2014/04/sergio-cabral-renuncia-atraves-de-carta-lidaem-solenidade-no-rio.html>

76 Cf <https://www.valor.com.br/politica/3592400/sergio-cabral-decide-nao-concorrer-nenhum-cargonas-eleicoes $>$

$77 \mathrm{Cf}<\mathrm{https}$ ://www.terra.com.br/noticias/brasil/politica/rj-cabral-comunica-exoneracao-de-secretarios-dopt-por-e-mail,6b5bcf47acec3410VgnVCM10000098cceb0aRCRD.html>

78 Cf <https://odia.ig.com.br/_conteudo/eleicoes2014/2014-08-12/movimento-lgbt-quer-partidoscomprometidos-com-a-causa-gay.html>

Vol. 01, N. 04, Out. - Dez., 2018 -www.revistas.unilab.edu.br/index.php/rebeh 
PMDB e o então senador e bispo licenciado Marcelo Crivella, que anunciou possíveis mudanças na gestão, além de recusar-se a assinar uma carta de compromisso com a política LGBTI $^{79}$. Mais ainda, Crivella era visto como o risco de um governo ultraconservador e religioso, que violaria diretamente as conquistas da gestão anterior ${ }^{80}$. Assim, Pezão foi eleito governador do Rio de Janeiro com $56 \%$ dos votos no segundo turno.

Inserção na estrutura do Governo, aporte de verbas, oferta de serviços, aliança progressista, visibilidade - serão esses indicadores de sucesso? As políticas de proteção à orientação sexual e identidade de gênero produziram desejo: por sua manutenção. Mas, afinal, quem estava a pagar os preços do progresso da política LGBTI nesse período?

\begin{abstract}
Nos últimos anos, o estado do Rio de Janeiro viveu o que é anunciado como o "melhor" projeto de combate à homofobia do Brasil: o Programa Rio Sem Homofobia. sob a coordenação da SuperDir [...]. Nestes oito anos de governo Cabral/Pezão, que se conclui no próximo dia 31 de dezembro [de 2014], observamos vários avanços, como a inauguração de Centros de Referências de Cidadania LGBT em Nova Friburgo, Niterói, Duque de Caxias e na capital, Rio de Janeiro, além de dezenas de campanhas de panfletagem e algumas portarias que avaliamos serem importantes, principalmente as relacionadas ao uso do nome social de travestis e transexuais.

O Grupo Conexão G, que trabalha prioritariamente com população LGBT de favelas, gostaria de fazer uma avaliação específica destas políticas, com foco nessa parcela da população. Como todos sabem, nós, moradores de favelas, já somos tradicionalmente esquecidos pelo poder público. Para além de sermos LGBT, sofrendo com toda a sorte de discriminações por causa de nossa orientação sexual/identidade de gênero, sofremos ainda com a adição de outros preconceitos, sejam eles por local de moradia, raça/etnia, condição social, entre outros.

O que questionamos é o que foi feito nestes oito anos de Programa Rio Sem Homofobia para esta parcela da população - a que mais sofre discriminação e violações dos seus direitos? Além de sermos a parcela da população LGBT mais vitimada pela homofobia (via agressões verbais ou físicas e as principais vítimas de assassinatos motivados pelo ódio), sofremos com o esquecimento do poder público. (CUNHA, 2014, online).
\end{abstract}

\title{
Gilmara Cunha, presidenta do Grupo Conexão G de Cidadania LGBT ${ }^{81}$, coloca
}

79 Cf <hhttps://ultimosegundo.ig.com.br/politica/2014-08-07/crivella-convida-gays-para-almocar-mas-senega-a-assinar-compromisso-com-grupo.html>

80 Marcelo Crivella foi eleito prefeito da cidade do Rio de Janeiro em 2016 e, em sua gestão, de fato impediu, proibiu, censurou e cortou recursos à diversas ações dirigidas especificamente à população LGBTI. $\mathrm{Cf}<$ https://jornalistaslivres.org/crivella-em-7-ataques-cultura-e-aos-lgbts-do-rio/>

81 "O Grupo Conexão G é uma organização da sociedade civil, fundada em março de 2006, originada de um grupo de jovens que resolveu realizar ações de reflexões sobre a homossexualidade em favelas. A trajetória desse coletivo é caracterizada por um interesse comum de trabalhar com a minimização dos preconceitos vivida por este segmento, de forma integrada e abrangente. Este projeto tem como foco as

Vol. 01, N. 04, Out. - Dez., 2018 - www.revistas.unilab.edu.br/index.php/rebeh 
em jogo os critérios para afirmação de uma política LGBTI como bem sucedida. Como ela destaca, há avanços concretos, que são listados. Mas parece que a construção de uma narrativa hegemônica de sucesso deixa rastros de silêncio e apagamento.

A população LGBT moradora de favelas, principalmente na cidade do Rio de Janeiro, é excluída pelo Programa Rio Sem Homofobia. O Centro de Referência LGBT da Cidade do Rio de Janeiro, além de estar instalado no prédio da Secretaria de Segurança Pública do estado do Rio de Janeiro, possui uma série de exigências para permitir o acesso ao prédio, além de ficar distante do subúrbio e de muitas comunidades, exigindo gastos com transporte até o centro da cidade. É válido ainda lembrar a eterna insegurança que as forças policiais e militares provocam na nossa população preta, pobre e favelada. Se somos suas principais vítimas, como pedir para um LGBT de favela sentir-se confortável neste ambiente?

[...] A população LGBT de favelas é esquecida e colocada à margem do Programa Rio Sem Homofobia. Nestes oito anos, não recebemos nenhum projeto e nenhuma atenção devida. Recentemente houve um evento para debater a situação da população LGBT em comunidades no prédio da Secretaria de Assistência Social e Direitos Humanos na Central do Brasil. Por que não debater dentro de uma favela? (CUNHA, 2014, online, grifos nossos).

Durante o governo Pezão, o Programa Rio Sem Homofobia interrompeu os atendimentos diversas vezes. Mas, ao desenhar uma constelação das ruínas do passado com os acontecimentos do presente, é necessário perceber onde o RSH já estava interrompido, mesmo em seu auge. Foi apresentado como parte de uma agenda progressista de direitos humanos, ao lado de uma política repressiva e violenta de ocupação das favelas, as UPPs ${ }^{82}$. Alguns andares da Central do Brasil separam a pasta de segurança da sede da Superdir. Afinal, a política pública LGBTI pode ser pensada de forma autônoma ao Estado? Gilmara indica diretamente o custo para sua manutenção:

\begin{abstract}
No entanto, quando um crime bárbaro acontece, recebemos toda a atenção para servir de material de divulgação deste programa. Neste fim de semana, aconteceu mais uma brutalidade com um companheiro e amigo, chamado Luiz Moura, cujo seu vulgo era Guinha[,] seu assassinato foi dia (20/12[/2014]) no Complexo do Alemão. Mais uma liderança, importante para o movimento de favelas, pois precisamos de pessoas que tenha o desejo de transformação e você tinha companheiro.
\end{abstract}

Vale lembrar que, assim como o Conexão $G$ denunciou e continua denunciando as perseguições aos LGBT moradores de favelas, Guinha também foi à imprensa denunciar essa violência. Mas o que foi feito de lá para cá? E o que

Favelas do Rio de Janeiro, tem como objetivo desenvolver ações de longo prazo para a minimização dos preconceitos e de outras formas de violência" (CUNHA, 2014, online).

82 Cf <http://www.ihu.unisinos.br/noticias/514847-unidades-de-policia-pacificadora-uma-nova-face-darepressao-policial-no-brasil $>$

Vol. 01, N. 04, Out. - Dez., 2018 -www.revistas.unilab.edu.br/index.php/rebeh 
As perguntas de Gilmara Cunha, do Grupo Conexão $\mathrm{G}^{83}$ e de outros militantes ${ }^{84}$ interrogam uma narrativa de sucesso do RSH. Polícias comunitárias com atuação repressiva e intervenções urbanas com remoções de famílias para os grandes eventos (MATOS, 2017) fizeram par com a política para suposta proteção da população LGBTI. O edifício da Central do Brasil é de importância simbólica e grande visibilidade, mas é, ao mesmo tempo, a sede das ações repressivas contra as favelas. Estas intervenções genocidas, por sinal, não foram interrompidas com a crise do Governo, muito pelo contrário: as mortes de civis por policiais militares, assim como de policiais executados, apenas cresceram nessa última gestão ${ }^{85}$.

Quem paga o preço do progresso?

\begin{abstract}
Ouso afirmar aqui que o preço da negociação dessa "cidadania de consolação" vem sendo mais cara àquelas e àqueles cujos corpos não se conformam às normas raciais, sexuais e de gênero. Nesses últimos 35 anos, desde o início institucionalizado do movimento LGBT brasileiro, é possível observar que as ambiguidades e contradições que permeiam a arena política de disputa por direitos sexuais, ainda que com supostos avanços no campo dos direitos civis, tem marcado o limite entre o desejo do Estado e a legitimidade social de uma identidade "aceita" e "tolerada" no limiar das inúmeras vidas que já foram ceifadas pela negligência desse mesmo Estado (IRINEU, 2017, p. 98).
\end{abstract}

A autonomia que permitiu flexibilidade de contratações, de alocação de recursos, de alianças políticas e de estratégias de comunicação, foi exacerbada nas subsequentes reduções e interrupções dos serviços do Programa RSH. Em algum momento, a história da política LGBTI no Rio de Janeiro foi narrada como uma vitória - de quem? Essa enunciação comporta, em si, o anúncio de sua ruína, pois não revela a destruição e barbárie que exigem para sua implementação e manutenção, até ser também devorada. Tarde demais. As migalhas não serão suficientes. O progresso exige cada vez mais para sua manutenção.

83 Importante destacar que a militância do Grupo Conexão G não se restringe a essas críticas; a organização realiza anualmente a Parada do Orgulho LGBT da Maré, além de diversos seminários sobre população LGBT favelada, oferta de atendimentos na sede da ONG e um curso preparatório para população LGBT retomar os estudos escolares, dentre outros. Cf <https://pt-pt.facebook.com/GrupoConexaoG/>

$84 \mathrm{Cf}<\mathrm{http}: / /$ www.ebc.com.br/cidadania/2014/12/coletivos-lgbt-de-comunidades-cobram-saude-eseguranca>

85 Cf <https://noticias.uol.com.br/cotidiano/ultimas-noticias/2017/12/18/numero-de-mortos-pela-policano-rio-ultrapassa-os-1000-e-ja-o-maior-em-quase-10-anos.htm>, e isso no período anterior ao início da intervenção militar federal no Estado.

Vol. 01, N. 04, Out. - Dez., 2018 - www.revistas.unilab.edu.br/index.php/rebeh 
Nossa história nos aponta não para o fim desses atos, mas para a reedição e aperfeiçoamento dessas mórbidas estratégias. [...] as ruas de São Paulo, as praias do Rio de Janeiro, são espaços que estilhaçam os espelhos de uma burguesia que se deseja ver asséptica, segura e feliz. São espaços que estilhaçam uma ética que se diz universal, mas que necessita da ação da polícia e das grades dos condomínios fechados para o seu bom funcionamento (BAPTISTA, 1999, p.47).

Talvez não retrocedemos a um momento anterior com a gestão Pezão/Dornelles, mas foi exacerbado o risco de morte e destruição que acompanha as vidas LGBTI. Não há proteção nem mesmo naquilo que seria um espaço seguro, o Centro de Cidadania; ele pode estar fechado, ou então violar trabalhadoras e trabalhadores. Mas, o reverso dessa cena de calamidade é perceber que ele já estava fechado para muitos, apesar das campanhas milionárias.

\section{Do que resta}

Walter Benjamin (2012) escreveu suas Teses sobre o conceito de história sem saber tratar-se de sua obra derradeira. Tirou a própria vida pouco tempo depois, quando estava preso na fronteira entre a França de ocupação nazista e a Espanha sob golpe fascista, em 1940. Denunciava, no século passado, que o assombro com o estado de degradação e destruição do que se entendia como uma sociedade moderna era correlato a uma expectativa errônea de que o tempo avança em um progresso incessante, para momentos melhores, e que as coisas não poderiam se desfazer ou deteriorar. Benjamin morreu, mas legou a tarefa de uma história inconclusa. O objetivo da obra deste autor, que inspira nosso texto, "[...] é menos o de "decretar" a revolução do que o de defender uma concepção de história como processo aberto, não determinado antecipadamente, em que as surpresas, as chances inesperadas, as oportunidades imprevistas podem surgir a qualquer momento" (LÖWY, 2005, p. 145)

O progresso parecia definitivo. Conferências de políticas públicas para população LGBTI, formações continuadas para profissionais da educação, conselhos de direitos, campanhas de enfrentamento à violência, editais de financiamento, centros de referência, programas de saúde especializados - essas ações falam de um momento em que a execução de políticas para população LGBTI e, mais especificamente, o Programa Rio Sem Homofobia, eram investimentos do Estado. Sua manutenção, entretanto, não é uma

Vol. 01, N. 04, Out. - Dez., 2018 - www.revistas.unilab.edu.br/index.php/rebeh 
garantia; são conquistas em disputa. Mais ainda, os cadáveres pelo caminho da execução das políticas indicavam que não era o bastante. A aparência de inovação camufla, por um lado, a barbárie e, por outro, a fragilidade da execução das políticas públicas.

Nesses termos, poderíamos falar em retrocesso da política LGBTI? As condições dos serviços são precárias e o risco de interrupções e encerramentos permanece - e parece ainda mais ameaçador com os resultados das recém realizadas eleições para o Governo do Estado e a Presidência da República, com vitória de candidatos de extrema-direita, com propostas de políticas reacionárias no campo dos direitos humanos e genocidas na segurança pública ${ }^{86}$. Mas a importância e o impacto destas políticas LGBTI interrogam e impossibilitam a ideia de simplesmente um retorno. A força de reivindicação está também nas narrativas sobre o que foi produzido ao longo dos anos ${ }^{87}$; essas histórias não foram apagadas, mas estão presentes nas vozes, nas memórias, nos escritos, nos materiais de divulgação, e inclusive nas janelas da Central do Brasil. E enquanto essas histórias não forem silenciadas e esses tantos corpos que lembram não forem mortos, é possível transmitir o que se passou. Nesse sentido, a luta é sempre nova. Há desmonte, destruição, mas é um lugar outro, e não aquele mesmo do passado. O convite de Walter Benjamin (2012) indica para um contraponto ao progresso, que não significa falar de regressão ou retrocesso, mas compreender que a situação é recorrentemente frágil, e que o progresso está a cobrar sempre um preço nas vidas e histórias. Se não nos apercebemos, talvez seja porque estivemos - provisoriamente - em aliança com a história dominante. Algo ocorre, tudo muda: empurrados para o limite das políticas públicas, novamente indesejados. E as vozes dos mortos, que estavam por demais caladas ou distantes, são novamente percebidas. Ora, qual era referência para lonjura? Será que havia barulho demais no entorno? O que o excesso de luz faz esconder? Por que os Centros de Cidadania não estavam nas favelas? O Estado ataca a população LGBTI - mais exatamente, partes dela, que antes se sentiam seguras, e que talvez hoje percebamos que a ameaça já era incessante. Agora, quem sabe, consigamos ouvir vozes daqueles que nunca pararam de gritar.

86 Com a eleição de Wilson Witzel, do Partido Social Cristão (PSC) para o Governo do Estado do RJ e de Jair Messias Bolsonaro, do Partido Social Liberal (PSL) para a Presidência da República. Vale destacar que houve também a eleição de diversos candidatos da extrema-direita para cargos legislativos e para o governo de outros estados.

87 Carrara \& Ramos (2017) e Rodrigues (2014) destacam a grande quantidade de pesquisas produzidas na Universidade do Estado do Rio de Janeiro sobre a política pública LGBT e a importância dos estágios profissionais nos Centros de Referência para a formação de estudantes de graduação.

Vol. 01, N. 04, Out. - Dez., 2018 - www.revistas.unilab.edu.br/index.php/rebeh 
Não é somente o futuro e o presente que permanecem abertos na interpretação benjaminiana do materialismo histórico, mas também o passado. O que quer dizer principalmente isto: a variante histórica que triunfou não é a única possível. Diante da história dos vencedores, da celebração do fato consumado, das rotas históricas de mão única, da inevitabilidade da vitória dos que triunfaram, é preciso retomar essa constatação essencial: cada presente abre uma multiplicidade de futuros possíveis (LÖWY, 2005, p. 157-158, grifos no original).

Em 2018, foi inaugurado um novo Centro de Cidadania do RSH em Volta Redonda, para atendimento ao Sul Fluminense, através de convênio com a prefeitura local $^{88}$. Além disso, a Prefeitura de São Gonçalo iniciou a implementação de um Centro de Referência Especializado de Assistência Social na Promoção da Cidadania LGBTI ${ }^{89}$. $\mathrm{O}$ colorido site do $\mathrm{RSH}^{90}$, que foi concebido e operado pela empresa contratada está fora do ar; com isso, parte dos registros de atividades e ações não está mais disponível. Mas muitos dos materiais publicitários são encontrados nas redes, nas paredes dos serviços públicos, nas residências da população fluminense. Algo ficou.

A história não estava acabada com o aparente sucesso do RSH, assim como não está com o que poderia parecer seu fracasso. Os registros de memórias e análises da execução do RSH, documentos de um momento histórico singular, fornecem pistas fundamentais para futuras ações do poder público e da sociedade civil, bem como balizadores e critérios para que os movimentos sociais exijam políticas de fato para a população LGBTI.

\begin{abstract}
Uma constatação entre a equipe que trabalha no serviço foi a de que a violência física não era a principal demanda, em termos numéricos, com a qual era preciso lidar. O maior empenho aparecia na direção da "garantia de direitos", o que fez com que uma outra compreensão sobre os sentidos da violência tenha surgido, associada com a violação do princípio de acesso à direitos e imiscuída em práticas cotidianas diversas. [...] Os centros recebem denúncias de diferentes formas de violência e discriminação, mas sobretudo lidam com "demandas" relacionadas à união estável - tanto para a sua realização quanto para a sua dissolução - conversão de uniões em casamento, retificação de registro civil, readequação sexual, depressão, ansiedade, mães buscando ajuda para lidar com filhos e filhas "LGBT" ou professores para lidar com seus alunos e abordar temas como 'diversidade sexual'. Muitas das "demandas" recebidas não estão necessária e/ou obviamente relacionadas à orientação sexual ou identidade de gênero, como o aconselhamento sobre direitos trabalhistas ou previdenciários, promoção de inserção no mercado de trabalho etc. Os casos
\end{abstract}

$88 \mathrm{Cf}<\mathrm{http}$ ://agenciabrasil.ebc.com.br/direitos-humanos/noticia/2018-03/rj-abre-novos-centros-deatendimento-mulheres-e-comunidade-lgbt $>$

$89 \mathrm{Cf}$

<http://www.pmsg.rj.gov.br/noticiaCompleta.php?cod=8472\&tipoNoticia=Desenvolvimento\%20Social\% 20title>

$90 \mathrm{Cf}<\mathrm{http}: / / \mathrm{www}$. riosemhomofobia.rj.gov.br>

Vol. 01, N. 04, Out. - Dez., 2018 -www.revistas.unilab.edu.br/index.php/rebeh 
em geral são encaminhados para outros equipamentos da rede pública de assistência e saúde (hospitais, UPAs [Unidades de Pronto Atendimento], abrigos, CAPS [Centro de Atenção Psicossocial], CRAS [Centro de Referência de Assistência Social] e CREAS [Centro de Referência Especializado de Assistência Social] etc); no caso de denúncias criminais, para delegacias, com o incentivo para que registro de ocorrência com o 'motivo presumido' homofobia seja lavrado; já questões jurídicas são encaminhadas para a Defensoria Pública e eventualmente para escritórios-modelo de universidades. Existe ainda muita procura por informação, especialmente nas ligações recebidas pelo Disque Cidadania LGBT, desde informações sobre datas de Paradas do Orgulho e outros eventos LGBT, sobre locais de distribuição de preservativos, até pessoas que ligam apenas para saber do que a linha se trata ou estudantes que procuram informações e dados para escrever trabalhos de curso. Mas parte da resposta ao que é trazido pelo "usuário", se encerra no atendimento mesmo, no que os profissionais dos centros costumam chamar de "acolhimento" e "escuta", e não obrigatoriamente acontece um encaminhamento externo ao serviço. (RODRIGUES, 2014, p. 221-222).

Se o DDH produziu dados importantes e estratégicos para ampliar a centralidade da denúncia de violência para promoção de cidadania, o imenso alcance do RSH trouxe demandas detalhadas, que possibilitam a articulação entre diversos serviços e setores. As intervenções nos sistemas judiciário e policial, aparelhos especialmente punitivos e repressivos, produziu efeitos importantíssimos nas próprias instituições ${ }^{91}$. Os anúncios do RSH como um programa pioneiro não são uma farsa ou um exagero; de fato, foi um alcance jamais visto na área, e com características absolutamente singulares, que permitiram um programa capaz de inventar novidades e intervir em pontos extremamente rígidos da política pública. Fazer a rede de equipamentos públicos funcionar, com acolhimento e atendimento à população LGBTI em suas necessidades de saúde, assistência, trabalho e educação, foi uma ação estratégica, pois estas (ainda) são políticas de Estado com uma parte considerável de servidores estatutários estáveis, possibilitando a continuidade de ações. Atuar diretamente no sistema prisional para garantia de direitos básicos (especialmente de pessoas trans) teve efeitos importantíssimos na manutenção e sobrevivência de parte da população ${ }^{92}$. Talvez uma ação necessária, daqui pra frente, seria

91 “As ações do programa Rio Sem Homofobia lograram desdobramentos interessantes. Além da possibilidade de apontar o "motivo presumido" como homofobia em registros de ocorrência, articulado junto à polícia civil e o uso do nome social em estabelecimentos públicos do estado, já mencionados anteriormente, foi realizada uma parceria com a ACADEPOL para a formação de 1200 agentes da polícia civil. [...] Outra ação, realizada em articulação com a Defensoria Pública do estado do Rio de Janeiro, foi a criação do NUDIVERSIS - Núcleo de Defesa da Diversidade Sexual e Direitos Homoafetivos. E aqui várias outras iniciativas poderiam ser mencionadas" (RODRIGUES, 2016, p. 211).

$92 \mathrm{Cf}<\mathrm{https}$ //extra.globo.com/noticias/rio/estado-regulamenta-direitos-da-populacao-lgbt-em-presidios16299922.html>

Vol. 01, N. 04, Out. - Dez., 2018 - www.revistas.unilab.edu.br/index.php/rebeh 
investir ainda mais na luta contra o encarceramento das populações empobrecidas e/ou marginalizadas.

A produção de conhecimento nos Centros de Cidadania LGBT, assim como registro dos dados estatísticos, é fundamental na produção de memória, história e instrumentos de luta. Em especial, a participação da UERJ com a vasta produção de pesquisas no RSH contribui para a resposta apontada por Irineu às tensões entre militantes em universidades e em movimentos LGBTI, qual seja,

[...] um convite à recusa de interpretações que reforçam a cisão entre academia e militância, ainda que seja possível compreender a distinção entre o "fazer" de cada uma delas; e ao reconhecimento de que, no desenho da hegemonia interna do movimento LGBT brasileiro, a identidade gay sobrepôs-se as contribuições históricas de travestis, transexuais e lésbicas, especialmente articulada ao formato de ativismo institucionalizado pós-advento da Aids (IRINEU, 2017, p. 97).

Os Centros de Cidadania e o Disque LGBT, em muito desmontados, lembram cenas e situações do antigo DDH. Talvez hoje, mais ainda, tenhamos o que aprender com o legado do CERCONVIDH, e das práticas que o antecederam, para enfrentar a crise que foi imposta ao Programa Rio Sem Homofobia. As chacinas em áreas periféricas continuam, como nos lembra Cunha (2014) e seu trabalho como parte do Grupo Conexão G. Não significa dizer que o RSH seja desimportante, mas indicar como é insuficiente. A locomotiva do progresso cobra um preço alto, sem perguntar quem quer pagá-lo. A proposta evolutiva é, por si só, um projeto de barbárie (BENJAMIN, 2012).

Será que o Estado é a salvação, ou eliminar-nos-á? Contamos com o aparelho estatal que regulamenta a vida, gerencia a exposição à morte e realiza execuções?

\footnotetext{
Se o direito é exercido e honrado, é porque há muitas pessoas o exercendo também, havendo ou não outra delas em determinado espaço. Cada 'eu' traz o 'nós' consigo, na medida em que ele ou ela entram ou saem por aquela porta, encontrando-se em um recinto desprotegido ou expostas lá fora na rua. [...] É, certamente, uma pessoa singular quem caminha por lá, que se arrisca em caminhar por lá, mas é também a categoria social que atravessa esse jeito de andar particular, esse movimento singular no mundo; e se há um ataque, ele tem como alvo o individual e a categoria social de uma só vez (BUTLER, 2016, p.37).
}

Levantar-se contra o desmonte do RSH não significa aceitar o Programa de qualquer forma, a qualquer custo. Decisões coletivas podem sustentar funcionamentos precários, provisórios, como já ocorreu com o DDH. Mas também pode ser a oportunidade

Vol. 01, N. 04, Out. - Dez., 2018 - www.revistas.unilab.edu.br/index.php/rebeh 
de apostar no voluntariado e nos projetos de atendimento e intervenção especializada através de Organizações Não-Governamentais (ONGs) e movimentos sociais. Se esta já é uma estratégia feita há décadas por diversas instituições no Rio de Janeiro, de forma a se contrapor à ausência ou ineficiência do Estado, agora há também todo o acúmulo de experiência profissional e acadêmica de profissionais e cientistas através do RSH. Assim, o trabalho sem remuneração pode servir para manter e ampliar o funcionamento de associações importantes e históricas do Rio de Janeiro, em vez de sustentar a abertura de serviços públicos precários em nome de um Estado decidido a eliminar-nos.

As mobilizações dos movimentos LGBTI fluminenses indicam a força política de grupos que não estão submetidos simplesmente a um partido ou uma gestão. E é também um duelo contra a indignidade de trabalhar sem receber salários; de oferecer serviços públicos precários; de enfrentar o isolamento das várias populações (e organizações) faveladas, dentre outras que estão fora do que se projetou como sucesso. Aos movimentos LGBTI fluminenses, talvez seja preciso continuar a enfrentar o risco de isolamento em uma temática - e uma política pública - específicas que, ainda que estratégicas e necessárias, não são as únicas condições e obrigações do Estado para a garantia de que a população LGBTI continue viva.

Escrever a história a contrapelo - expressão de um formidável alcance historiográfico e político - significa, então, em primeiro lugar, a recusa em se juntar, de uma maneira ou de outra, ao cortejo triunfal que continua, ainda hoje, a marchar sobre daqueles que jazem por terra (LÖWY, 2005, p. 73).

Discutir a história não significa dizer como deveria ter sido, ou o que seria melhor; essa seria uma mirada progressista ao passado. Em jogo, talvez, seja a recuperação das lutas que aconteceram e daqueles que pereceram no caminho. Gaio et al (2006) recordam do assassinato de Cláudio Alves dos Santos com indignação pela sua morte e pelos efeitos no serviço, mas também como parte de uma denúncia dos abusos e violações cometidos contra defensores de direitos humanos no Brasil. A morte de Guinha ${ }^{93}$, homenageado no texto de Gilmara Cunha (2014), fala da perda do companheiro e do seu desejo de transformação. Sua vida foi interrompida; entretanto, o desejo e a história podem ser

\footnotetext{
93 Para outras informações $\quad$ sobre $\quad$ crime, $\quad$ cf <https://www.brasil247.com/pt/247/rio247/164432/Homofobia-do-tr\%C3\%A1 fico-diz-Nascimento-sobreGuinha.htm> e <https://odia.ig.com.br/_conteudo/noticia/rio-de-janeiro/2014-12-21/lider-comunitario-docomplexo-do-alemao-recebia-ameacas-de-morte.html $>$
}

Vol. 01, N. 04, Out. - Dez., 2018 - www.revistas.unilab.edu.br/index.php/rebeh 
transmitidos. Esses relatos não permitem que esqueçamos; são ações contra crimes que, para além disso isso, seguem impunes. Ora, não podemos ressuscitar os mortos; entretanto, talvez seja possível aproximarmo-nos daquilo que sua perda nos deixa como legado.

\section{Referências}

BAPTISTA, Luis Antônio. Cidade dos Sábios. São Paulo: Summus, 1999.

BENJAMIN, Walter. Origem do drama trágico alemão. Rio de Janeiro: Autêntica, 2016.

Magia e técnica, arte e política: ensaios sobre literatura e história da cultura. $8^{\mathrm{a}}$ edição revista [Obras Escolhidas v.1]. São Paulo: Brasiliense, 2012.

BUTLER, Judith. Corpos que ainda importam. In: COLLING, Leandro (ORG). Dissidências sexuais e de gênero. Salvador: EDUFBA, 2016, p.19-42.

COTTA, Diego de Souza. Conquistas, impasses e desafios da cidadania LGBT no Rio de Janeiro. Dissertação (Mestrado) - Programa de Pós-Graduação em Mídia e Cotidiano/Universidade Federal Fluminense, 2016.

CUNHA, Gilmara Santos. Grupo Conexão G luta pelos direitos LGBT nas favelas. Disponível em: <https://www.brasil247.com/pt/247/favela247/164468/GrupoConex\%C3\%A3o-G-luta-pelos-direitos-LBGT-nas-favelas.htm>. Acesso em: 29 ago.2018. Datado de 22 dez. 2014.

GAIO, Carlos Eduardo; ARAGÃO, Daniel Maurício; FRIGO, Darci; GORSDORF, Leandro; CARVALHO, Sandra. Na linha de frente: defensores de direitos humanos no Brasil: 2002 - 2005. Rio de Janeiro: Justiça Global; Curitiba: Terra de Direitos, 2006.

FOUCAULT, Michel. Microfísica do Poder. Rio de Janeiro: Graal, 1979.

GAGNEBIN, Jeanne Marie. Lembrar escrever esquecer. São Paulo: Editora 34, 2009.

GARCIA, Aline Monteiro. O que sou? Do que gosto? Identidades em análise nas lutas em defesa da diversidade sexual. Dissertação (mestrado) - Programa de PósGraduação em Psicologia/Universidade Federal Fluminense, 2011.

IRINEU, Bruna Andrade. Exercendo a "crítica lesbofálica" às demandas por uma “cidadania LGBT" no contexto brasileiro (2003-2016). Periodicus, n. 7, v. 1, maioout. 2017, p. 78-101.

Vol. 01, N. 04, Out. - Dez., 2018 - www.revistas.unilab.edu.br/index.php/rebeh 
LÖWY, Michel. Walter Benjamin: Aviso de incêndio: uma leitura das teses "Sobre o conceito de história". São Paulo: Boitempo, 2005.

MATOS, Adriane Henderson de. Cidade Olímpica, cuidado e política: narrativas de um CAPS-AD. Dissertação (Mestrado) - Programa de Pós-Graduação em Psicologia/Universidade Federal Fluminense, 2017.

MELlO, L.; AVELAR, R. B.; MAROJA, D. Por onde andam as Políticas Públicas para a População LGBT no Brasil. Revista Sociedade e Estado, v. 27, n. 2, mai/ago, 2012, p. 289-312.

RAMOS, Sílvia; CARRARA, Sérgio. A constituição da problemática da violência contra homossexuais: a articulação entre ativismo e academia na elaboração de políticas públicas. PHYSIS: Revista de Saúde Coletiva, n.16, v.2, 2006, p. 185-205.

RODRIGUES, Sílvia Aguião. Fazer-se no "Estado": uma etnografia sobre o processo de constituição dos "LGBT" como sujeitos de direitos no Brasil contemporâneo. Tese (Doutorado) - Programa de Pós-Graduação em Ciências Sociais/Universidade Estadual de Campinas, 2014.

SALLES, Carolina Motta Cardoso. Histórias que importam: sobre trânsitos e fronteiras. Dissertação (Mestrado) - Programa de Pós-Graduação em Psicologia/Universidade Federal Fluminense, 2018.

SENNA, Mônica de Castro Maia. Gestão Estadual do SUAS no Rio de Janeiro: iniciando um debate. Argum, v. 8, n. 2, p. 51-63, maio/ago. 2016.

TEIXEIRA, Camila Cristina da Silva. Políticas Públicas para a População LGBT no Estado do Rio de Janeiro: A experiência dos Centros de Referência da Cidadania LGBT. Revista de Políticas Públicas e Segurança Social, v. 1, n. 1, 2017, p. 13-35.

TREVISAN, João Silvério. Homocultura \& Política Homossexual no Brasil: do Passado ao Por-vir. In: COSTA, Horácio; BENTO, Berenice; GARCIA, W.; INÁCIO, E.; PERES, Willian Siqueira. (orgs). Retratos do Brasil Homossexual: Fronteiras, subjetividades e desejos. São Paulo: EdUSP/Imprensa Oficial, 2010, p. 49-59.

\title{
A STUDY AMONG RUINS:
}

\section{THE RIO WITHOUT HOMOPHOBIA PROGRAM AND THE LGBTI POLITICS OF RIO DE JANEIRO}

\begin{abstract}
Who pays the price when the Rio Without Homophobia (originally, Rio Sem Homofobia or RSH) Program was dismantled by the Government of the State of Rio de Janeiro? What makes it possible to announce a policy as successful or failed? What are the necessary conditions for the execution of public services for the LGBTI population?
\end{abstract}

Vol. 01, N. 04, Out. - Dez., 2018 -www.revistas.unilab.edu.br/index.php/rebeh 
As the genealogy worked by Michel Foucault, this article retrieves records related to some moments of the RSH Program to understand struggles, movements and historical processes in operation. It is not an exhaustive and conclusive search for information, not even an attempt to uncover a supposedly true and definite past. Nevertheless, we believe that this text can contribute to the understanding of the present time and if do not respond, at least try to extract implications of the questions asked. The text is divided into six items, organized from the Walter Benjamin's concept of constellation which groups different ideas by provisional similarities. First, the presentation of methodological markers. Second, the operation of the RSH in the last administration of the Government of the State of Rio de Janeiro. Third, the analysis of processes related to the creation, inauguration and implementation of the Program. Fourth, the discussion regarding services before the RSH, executed by social movements, with public financing. Fifth, critics to the idea of successful narratives, in an attempt to make possible different perspectives on the present. Finally, the last point about experiences and responsibilities that still remain.

Keywords: Rio Without Homophobia; Genealogy; LGBTI movement; Public policy.

Recebido em: 09/09/2018

Aceito em: 23/11/2018

Vol. 01, N. 04, Out. - Dez., 2018 -www.revistas.unilab.edu.br/index.php/rebeh 